\title{
Article
}

\section{Provenance analysis of sediments in the south-east Aegean during the Upper Quaternary: a composite approach based on bulk and clay mineralogy and geochemistry}

\author{
Georgia Leontopoulouㄴ, Georgios E. Christidis ${ }^{1 *}$ (D), Grigorios Rousakis², Noémi S. Müller ${ }^{3}$, George Papatheodorou \\ and Maria Geraga ${ }^{4}$ \\ ${ }^{1}$ Technical University of Crete, School of Mineral Resources Engineering, 73100 Chania, Greece; ${ }^{2}$ Hellenic Center for Marine Research, Institute of Oceanography, \\ 46,7Km Athens-Sounio Av. Mavro Lithari, PO Box 712, 19013, Anavissos, Attica, Greece; ${ }^{3}$ Fitch Laboratory, British Archaeological School at Athens, Souedias Street \\ 52, 10676 Athens, Greece and ${ }^{4}$ University of Patras, Department of Geology, 26500 Rio, Patras, Greece
}

\begin{abstract}
Sediments from the ST5 deep-sea bottom core collected from the south-east Aegean Sea between Symi and Tilos islands, Greece, were examined by quantitative mineralogical analysis and geochemical analysis to infer provenance and palaeoenvironmental control over sediment deposition. The mineralogical composition comprises carbonates (mainly calcite and Mg-calcite), quartz, feldspars, serpentine, amphibole and clay minerals. Chlorite is the most abundant clay mineral, whereas smectite and illite are less abundant than in the sediments in the south-west Aegean and the Cretan Sea. Semi-quantitative analysis of clay minerals from oriented clay fractions overestimates significantly the smectite content and underestimates the abundances of illite, chlorite and kaolinite. The studied sediments are enriched in $\mathrm{MgO}$, Ni and $\mathrm{Cr}$, which decrease in abundance with decreasing depth, following the distribution of serpentine. By contrast, the abundances of $\mathrm{SiO}_{2}, \mathrm{Al}_{2} \mathrm{O}_{3}, \mathrm{Fe}_{2} \mathrm{O}_{3}, \mathrm{Na}_{2} \mathrm{O}$ and $\mathrm{K}_{2} \mathrm{O}$ increase upcore. The regional $\mathrm{S} 1$ sapropel horizon is enriched in $\mathrm{V}$ and Co and has considerably greater $\mathrm{Ba} / \mathrm{Al}$ ratios than the remaining sequence. The mineralogical and geochemical relationships indicate a strong ultrabasic influence, probably from the Marmaris ophiolite in the Lycian nappes. The clay mineral distribution suggests that the smectite was mainly of volcanogenic origin, the illite was supplied by the nearby landmasses of west Anatolia and the islands of Rhodes, Tilos and Symi and the contribution from the south-east Mediterranean was limited or totally lacking. The combined use of the mineralogical and geochemical analysis of bulk sediments rather than the clay fractions is not only extremely useful in tracing sediment provenance in relatively closed basins, but it also enables a more realistic assessment of the importance of water circulation patterns on sedimentation processes in such environments.
\end{abstract}

Keywords: Aegean Sea, clay minerals, mineralogical composition, provenance, Rietveld analysis, ultrabasic rocks

(Received 9 August 2021; revised 27 December 2021; Accepted Manuscript online: 7 January 2022; Associate Editor: Warren D. Huff)

The provenance of the fine-grained suspended particulate matter (SPM) of marine hemipelagic sediments is of particular importance in sedimentological studies because it provides information about the sedimentary processes that control transport and deposition. Sedimentary variability heavily depends on provenance, but it is also affected by climatic factors (e.g. climate change) and in the Anthropocene (cf. Zalasiewicz et al., 2011) by human activities. This provenance may be determined from mineralogical analysis of the clay minerals that are associated with variable weathering processes, which in turn are linked with climatic variations through geological time (e.g. Vanderaveroet et al., 1999; Thiry, 2000; Bout-Roumazeilles et al., 2007; Adriaens et al., 2018, among many others). Therefore, clay minerals in recent

\footnotetext{
*E-mail: christid@mred.tuc.gr

Cite this article: Leontopoulou G, Christidis GE, Rousakis G, Müller NS, Papatheodorou G, Geraga M (2021). Provenance analysis of sediments in the south-east Aegean during the Upper Quaternary: a composite approach based on bulk and clay mineralogy and geochemistry. Clay Minerals 56, 229-249. https://doi.org/10.1180/clm.2022.2
}

marine and terrestrial sedimentary successions have received considerable interest in palaeoclimatic and palaeoceanographic studies (Martinez-Ruiz et al., 2000; Dera et al., 2009; Sabatier et al., 2010; Ergin et al., 2012; Garzanti et al., 2014; Lister et al., 2015). This is because in such environments and ages of sediment the distribution of clay minerals is not affected significantly by diagenesis but is determined by the existence of multiple sources, the differential stability of clay minerals to alteration, potential climatic variations, the maturity of soil profiles and transport routes and depositional processes (Thiry, 2000).

Provenance and palaeoclimatic interpretations using clay minerals are based on using semi-quantitative methods. The semi-quantitative approaches have several shortcomings (e.g. Leontopoulou et al., 2019), and recently, more complex methods have been employed that utilize X-ray diffraction (XRD) profile modelling of the clay fractions with specialized computer codes (Zeelmaekers et al., 2015; Kemp et al., 2016; Adriaens et al., 2018). In an attempt to overcome the shortcomings of the semiquantitative methods, which, among other shortcomings,

(C) The Author(s), 2022. Published by Cambridge University Press on behalf of The Mineralogical Society of Great Britain and Ireland. This is an Open Access article, distributed under the terms of the Creative Commons Attribution licence (https://creativecommons.org/licenses/by/4.0/), which permits unrestricted re-use, distribution, and reproduction in any medium, provided the original work is properly cited. 
overestimate significantly the smectite contents of sediments, Leontopoulou et al. (2019) proposed a novel approach. This approach is based on the analysis of the bulk sediments coupled with the bulk geochemistry of the sediments and specialized tests on the oriented clay fractions (heating at $530^{\circ} \mathrm{C}$ followed by ethylene glycol (EG) solvation), rather than the semi-quantitative estimation of clay minerals from oriented clay fractions. The combination of quantitative bulk mineralogical analysis with bulk geochemistry was used in the past in sediments offshore from Brazil (Kronberg et al., 1986). However, the mineralogical analysis was normative as it was calculated from the chemical composition of the sediments (cf. Kronberg et al., 1986). Moreover, the thermal characteristics of individual clay minerals and their possible significance for data interpretation were not considered.

The clay mineralogical composition of Aegean marine sediments has been studied extensively in the past, being heavily reliant on semi-quantitative analysis (Aksu et al., 1995a; Bayhan et al., 2001; Karageorgis et al., 2005; Ehrmann et al., 2007, 2013; Ergin et al., 2007, 2012; Poulos, 2009). These studies consider the Nile-derived sediments as an important component of the sediments in the south-east Aegean (cf. Ehrmann et al., 2007, 2013; Poulos 2009). However, in a recent study we showed that the contribution of south-east Mediterranean SPM to the sediments of the eastern Cretan Sea and the south-west Aegean Sea is negligible (Leontopoulou et al., 2019). In the present contribution we examine the provenance of sediments of the ST5 core in the south-east Aegean Sea (Fig. 1) following the same analytical approach and protocols for the bulk sediments and the clay fractions. This particular core was selected because of its excellent location in the area where the south-east Mediterranean Sea meets the Aegean region. Therefore, any contribution from the south-east Mediterranean, as has been postulated in previous studies (Ehrmann et al., 2007, 2013; Poulos, 2009), if it exists, might be traced and verified, thus testing the sensitivity of the approach.

The south Aegean Sea links the Levantine Basin and the Ionian Sea through the eastern and western straits of the Cretan Arc (Fig. 1) (Lykousis et al., 2002). The upper sea layer is probably occupied by the Modified Atlantic Water originating from the Ionian Sea, the Levantine Surface Waters (LSWs) originating from the Levantine Sea and the Black Sea Water from the north. Three water masses occupy the intermediate and deep waters of the area: the Cretan Intermediate Water formed locally; the Transitional Mediterranean Water coming through the eastern and western Cretan Arc Straits; and the Cretan Deep Water formed locally. In addition, the dense north Aegean water sinks, flows to the south Aegean Sea and then is directed to the eastern Mediterranean Sea through the Cretan Straits, contributing to the rejuvenation of the bottom water (Tripsanas et al., 2016). Within this context, the south-east Aegean Sea displays two main differences compared to the Cretan Sea and the south-west Aegean Sea: firstly, it is bordered by the estuaries of several rivers, which drain the nearby west Anatolian landmass; and secondly, circulation patterns in the south-east Aegean Sea are different from those of the Cretan Sea and the south-west Aegean Sea. The south-east Aegean Sea is dominated by the LSWs originating from the southeast Mediterranean Sea, which thus might contribute to the composition of sediments in the area, as has been proposed in the past (Ehrmann et al., 2007, 2013; Poulos, 2009). On the other hand, the Cretan Sea is dominated by rotating currents (Cretan Sea gyres) within the basin with limited input from the south-west and south-east Aegean Sea (Lykousis et al., 2002). Finally, the south-west Aegean Sea is characterized by the dense north
Aegean water that transports SPM from the north and central Aegean Sea and the presence of the Myrtoan Sea Gyre (Lykousis et al., 2002; Tripsanas et al., 2016).

This paper re-examines the clay mineral relationships proposed in previous studies in the south-east Aegean area, discusses sediment provenance and interprets the bulk and clay mineralogy and geochemistry according to the existing palaeoclimatic and palaeoceanographic models for the broader area, considering the various sedimentological settings in the various Aegean areas. In addition, the role of Asia Minor vs the Nilotic region as regards the provenance of SPM in the south-east Aegean Sea is discussed.

\section{Materials and methods}

\section{Core sampling and sample preparation}

The present study focuses on the analysis of sediment samples obtained from the ST5 gravity core $\left(36^{\circ} 30.752^{\prime} \mathrm{N}, 27^{\circ} 41.511^{\prime} \mathrm{E}\right.$, water depth $688 \mathrm{~m}$, length $381 \mathrm{~cm}$ ) recovered during a Research Vehicle of the Hellenic Center for Marine Research oceanographic cruise on 20 June 2011 near Symi Island, south-east Aegean Sea (Fig. 1). The gravity core was split longitudinally and we received one half of the core, which was photographed and described macroscopically at the laboratory. A total of 59 subsamples were collected for mineralogical and geochemical analysis from the half-core, each consisting of $\sim 4 \mathrm{~g}$ of dried material. Before the analyses, the samples were washed repeatedly with deionized water to remove soluble salts until electric conductivity was $<50 \mu \mathrm{S} \mathrm{m}^{-1}$. The gravity core contains a dark-coloured mud unit that corresponds to sapropel S1, which was subsequently confirmed by organic carbon $\left(\mathrm{C}_{\mathrm{org}}\right)$ analysis. Sapropel $\mathrm{S} 1$ consists of two discrete intervals, referred to hereafter as the lower (S1a) and upper (S1b) layers, which are separated by an interval of lighter colour corresponding to the $\mathrm{S} 1$ interruption caused by re-ventilation of large parts of the basin (Geraga et al., 2000; Mercone et al., 2001; Gogou et al., 2007; Triantaphyllou et al., 2009).

\section{Grain-size analysis}

Grain-size analysis was carried out on the bulk samples using laser diffraction on dilute suspensions of the washed samples with a Mastersizer S (Malvern Instruments), without the use of a deflocculant. The proportions (\%) of sand, silt and clay fractions were calculated according to the Udden-Wentworth scale (Wentworth, 1922) from the cumulative size distributions provided from the particle-size analyses. The classification of sediments was conducted according to the approach of Folk (1974).

\section{Mineralogical analysis}

The mineralogical composition of the sediments was examined using XRD with a Bruker D8 Advance diffractometer equipped with a Lynx-eye silicon strip detector, using Ni-filtered $\mathrm{Cu}-\mathrm{K \alpha}$ radiation $(40 \mathrm{kV}, 40 \mathrm{~mA}), 0.298^{\circ}$ divergence and anti-scatter slits, as well as a step size of $0.019^{\circ} 2 \theta$, with a 63.5 s count time per step. Data were evaluated using the $E V A^{\oplus}$ software provided by Bruker. The bulk mineralogy was determined on random powders prepared after grinding of the sediments by hand with an agate pestle and mortar in acetone medium, subsequent drying at $60^{\circ} \mathrm{C}$ and mounting by careful side loading onto $\mathrm{Al}$ holders 


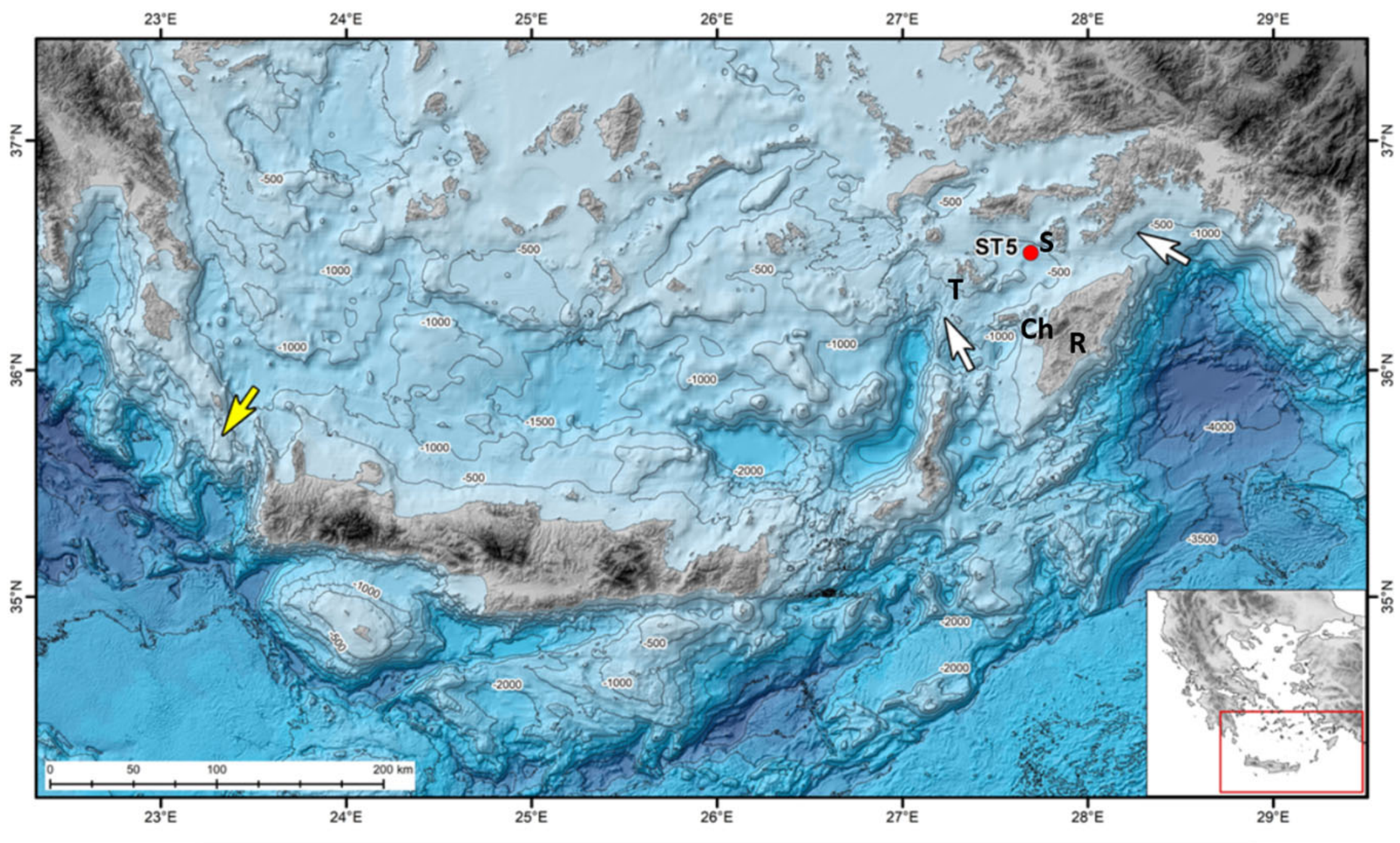

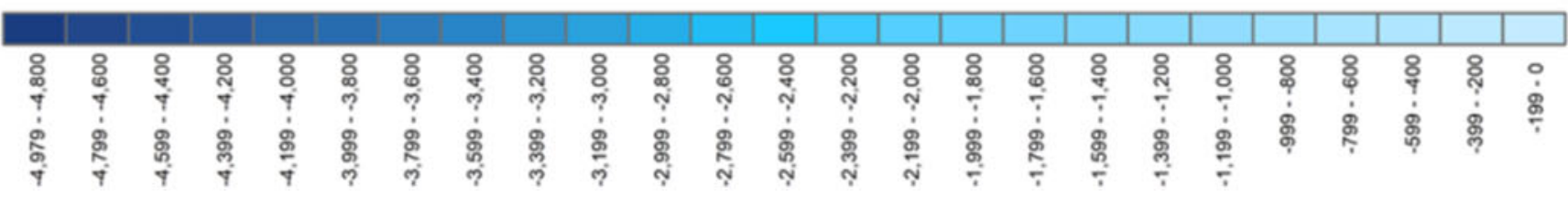

Fig. 1. Location of the investigated core ST5. The arrows indicate the eastern (white arrows) and western (yellow arrow) straits of the Cretan Arc. Ch=Chalki Island; R=Rhodes Island; $S=S y m i$ Island; $T=T$ ilos Island. 
to avoid preferred orientation. The final particle size of the sediments analysed by XRD was $\sim 3 \mu \mathrm{m}$ (tested by laser diffraction). The clay mineralogy was determined from $<2 \mu \mathrm{m}$ fractions of the as-received samples separated from suspension by differential settling according to Stoke's Law and then spread onto glass slides to form oriented mounts and allowed to dry in air. The carbonates were not dissolved from the clay fraction in an attempt to verify the possible differentiation of the various carbonate phases in that fraction (see 'Results' section). The clay minerals were identified from air-dried (AD) and EG-solvated slides, as well as slides heated at $530^{\circ} \mathrm{C}$. In addition, $\sim 40$ separate aliquots of the heated slides were subsequently EG-solvated. This allowed for differentiation of the dioctahedral smectites with low dehydroxylation temperatures (Fe-montmorillonite, nontronite and/or beidellite) from dioctahedral smectites with higher dehydroxylation temperatures (Drits et al., 1998). The EG-solvated slides were used to determine the abundances of smectite, illite, kaolinite and chlorite according to the approach of Biscaye (1965). In brief, the approach uses the integrated areas of the 001 basal reflections of smectite, illite and kaolinite and the area of the 002 basal reflection of chlorite, which are multiplied by suitable factors and normalized to $100 \%$. Finally, the $7 \AA$ peak is divided between kaolinite and chlorite in proportion to the fractions of these minerals, calculated from the areas of the 002 peak of kaolinite and of the 004 peak of chlorite at $\sim 25^{\circ} 2 \theta$.

The mineral phases in the bulk sediments were quantified using a Rietveld-based refinement routine with the BGMN code (Autoquan ${ }^{\circledast}$ software version 2.80; Seifert). The Rietveld method compares the full experimental profile with the calculated XRD profile, with each data point ( $2 \theta$ step) being an independent observation. Although it was originally used for the structure refinement of minerals (cf. Post \& Bish, 1989), it has evolved to become an efficient and reliable method for the quantitative analysis of soft sediments and industrial minerals (Snellings et al., 2010; Bish \& Plötze, 2011; Karageorgis et al., 2012; Adriaens et al., 2018; Leontopoulou et al., 2019). Due to the small amount of material in each sample extracted originally from the half-core and the need to perform several analyses from this small sample, the addition of an internal standard was not performed to estimate the error of the method. However, Leontopoulou et al. (2019) recently used a $\mathrm{ZnO}$ internal standard to estimate the absolute error (estimation of accuracy) of the quantitative determinations in similar Aegean sediments. The error estimated from the internal standard was $\pm 0.5 \%$ at $15 \%$ abundance ( $\sim 3.4 \%$ relative error). The reproducibility (estimation of precision) of the quantitative analyses, estimated from duplicate analyses of representative samples, was better than $\pm 2 \%$ for abundances of $>10 \%, \pm \sim 4 \%$ for abundances of $5-10 \%, \pm \sim 7 \%$ for abundances of $1.5-5.0 \%$ and $\pm \sim 10 \%$ for abundances of $<1.5 \%$. A detailed description of the analytical approach was given by Leontopoulou et al. (2019). An independent estimation of the accuracy of the determination of total carbonate contents (calcite, $\mathrm{Mg}$-calcite, aragonite and dolomite) was obtained from X-ray fluorescence (XRF) analysis of the bulk sediments (see 'Results' section).

Finally, the abundances of smectite, illite, kaolinite and chlorite determined using the Rietveld approach were normalized to $100 \%$ and were compared with those obtained from the semiquantitative approach of Biscaye (1965) described previously.

\section{Geochemical analysis}

All sediment samples were analysed for major and trace elements using wavelength-dispersive XRF spectroscopy with a S8 Tiger
XRF spectrometer with a Rh excitation source (Bruker), using a custom calibration based on 43 certified reference materials, which had been developed for the analysis of soils and ceramics prepared as glass beads (Georgakopoulou et al., 2017). Loss on ignition (LOI) was determined by placing $\sim 2 \mathrm{~g}$ of pulverized, dried sample in a porcelain crucible and heating to $1050^{\circ} \mathrm{C}$ for $2 \mathrm{~h}$ in a muffle furnace. Glass beads were subsequently prepared on an automatic fluxer with $1.5 \mathrm{~g}$ of the ignited sample and $7.5 \mathrm{~g}$ of a mixture of lithium metaborate/lithium tetraborate.

Organic carbon $\left(\mathrm{C}_{\text {org }}\right.$; wt.\%) was determined for all samples by means of a CHNS-O elemental analyser (LECO). Carbonates were removed previously by dissolution with $1 \mathrm{~N} \mathrm{HCl}$, stirring for $2 \mathrm{~h}$ and subsequent washing of the sediments with distilled water and drying at $60^{\circ} \mathrm{C}$. Aliquots of $10-15 \mathrm{mg}$ of the samples were introduced into the CHNS-O analyser.

\section{Radiocarbon dating and age model}

The chronostratigraphy of the core is based on four accelerator mass spectrometry (AMS) ${ }^{14} \mathrm{C}$ ages. The analyses were performed by Beta Analytic Laboratories in Florida (USA) on cleaned, handpicked planktonic foraminifera. Conventional ${ }^{14} \mathrm{C}$ ages were calibrated with the CALIB v. 5.0.2 program (Stuiver \& Reimer, 1993; Stuiver et al., 1998) and the MARINE0 ${ }^{14} \mathrm{C}$ calibration dataset for $1 \sigma$ intervals (Hughen et al., 2004). Regional reservoir age corrections $(\Delta \mathrm{R})$ of $149 \pm 30$ years for sapropel intervals (Facorellis et al., 1998) and of $58 \pm 85$ years outside the sapropel (Reimer $\&$ McCormac, 2002) were applied.

\section{Scanning electron microscopy}

The clay fractions of selected samples were gold-coated and were studied using scanning electron microscopy (SEM) with a JEOL 6400 microscope equipped with an energy-dispersive spectrometer (EDS) and a wavelength-dispersive spectrometer.

\section{Core description}

Five lithological units were identified in core ST5 based on the colour, grain size, $\mathrm{C}_{\text {org }}$ and sedimentary structures (Fig. 2). The first unit $(0-5 \mathrm{~cm})$ consists of dull yellow, oxidized, water-rich mud. The second unit $(5-58 \mathrm{~cm})$ consists of greyish-olive waterrich mud. The third unit $(58-141 \mathrm{~cm})$ consists of olive-grey plastic mud with sporadic organic matter-rich lenses. The fourth unit $(141-185 \mathrm{~cm})$ corresponds to the sapropel sequence (sapropel S1) and consists of darker olive-grey sapropelic mud. The sapropel S1 deposition has been divided in two dark sublayers: S1a and S1b (S1a: 165-185 cm; S1b: 141-160 cm below sea floor (bsf)). Between these two sapropel sublayers is the characteristic distinct interruption of sapropel S1 at $160-165 \mathrm{~cm}$. Within the sapropel sequence, the maximum $\mathrm{C}_{\text {org }}$ content $(1.77 \%)$ occurs at $175.5 \mathrm{~cm}$. The fifth unit $(185-381 \mathrm{~cm})$ is a stiff olive-grey mud differentiated from the previous unit by a colour transition from olive-grey 2,5GY 5/1 to olive-grey 5GY 5/1.

\section{Results}

\section{Grain size}

The downcore grain-size distribution of core ST5 is shown in Fig. 2. The sediments consist of clay (28-89\%, average $60 \%)$ and silt (11-62\%, average $39 \%)$, while the sand content does 
(a)

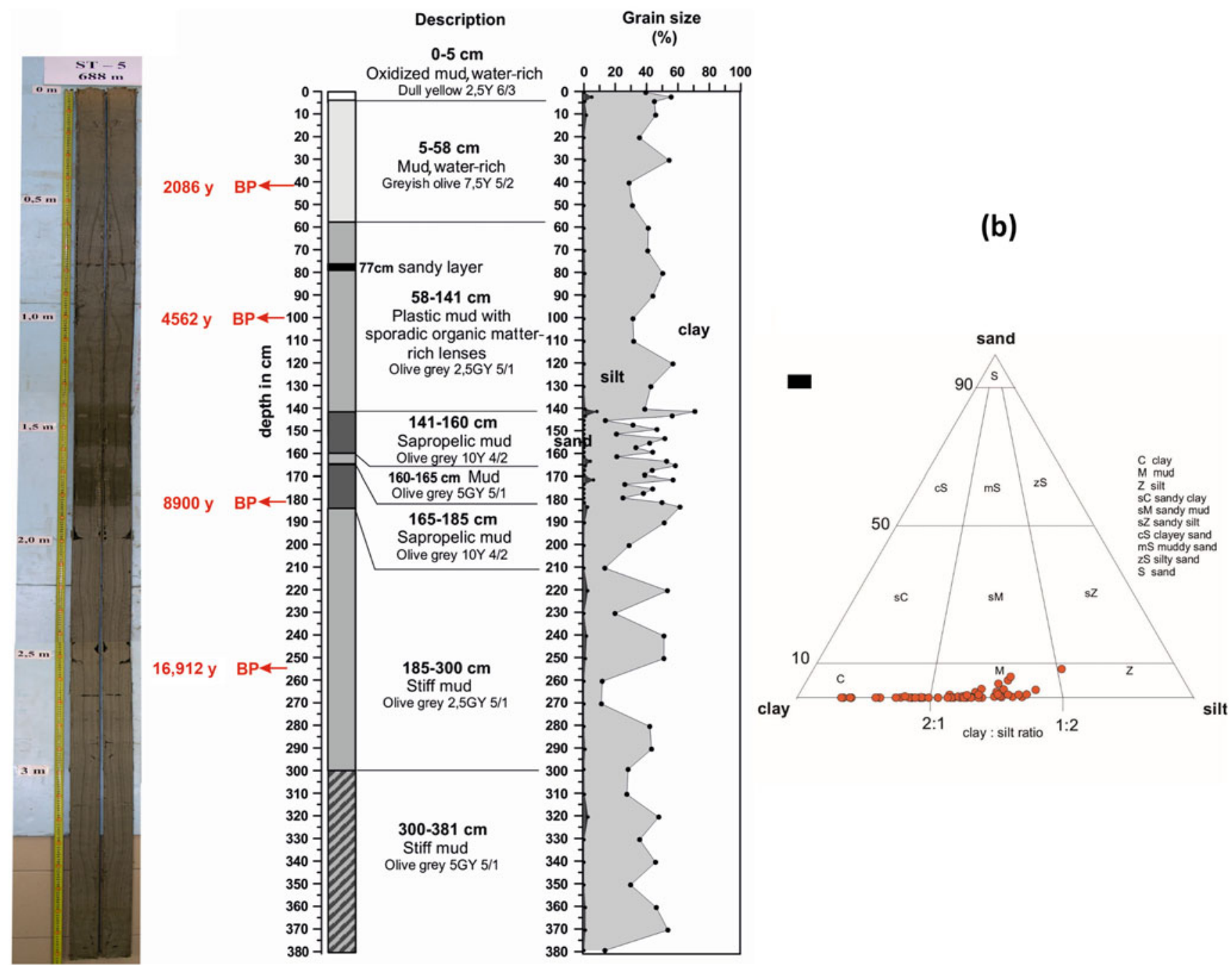

Fig. 2. (a) Description of lithological units and downcore evolution of the sediment size fractions of core ST5. The darker areas indicate sapropel S1. The vertical axis denotes the depth bsf. (b) Classification of the ST5 sediments according to the Folk (1974) scheme.

not exceed $10 \%$ (average 1\%). The studied sediments are finegrained, with the silt + clay fractions exceeding $94 \%$, while the average median particle size $\left(D_{50}\right)$ is $5.1 \mu \mathrm{m}$. The clay content increases with depth, while the sand content does not show significant differentiation. No particular trend was observed in the distribution of the silt fraction. According to Folk's (1974) classification scheme, the sediments are classified as muds and clays (Fig. 2b). The $D_{50}$ values in this core also remain within the range of fine-grained silt $(<7.8 \mu \mathrm{m})$ according to the UddenWentworth scale, and the distribution of $D_{50}$ tends to decrease with depth, similar to the clay content. In addition, $D_{50}$ tends to decrease in the top of the sapropelic layer S1b, while the sand content increases in the S1 horizon. Thus, most of the sapropel samples are coarser in general compared to the surrounding sediments (Fig. 2). By contrast, the pre- and post-sapropel sediments cannot be clearly differentiated based on their grain size.

\section{Bulk mineralogy}

The downcore distribution of major minerals is depicted in Fig. 3 and a summary of the results (average concentrations, standard deviations, minimum and maximum values) is listed in Table 1. Representative XRD traces are shown in Fig. S1, and the mineralogical compositions of all samples are listed in Table S1. The bulk mineralogical compositions comprise mainly carbonate minerals (calcite, Mg-calcite, aragonite and dolomite), ranging from 32.5 to $43.9 \%$ in total. Calcite ranges between 17.2 and 26.6 wt.\% (average 22.1 wt.\%), Mg-calcite ranges between 5.2 and 12.0 wt.\% (average 8.1 wt.\%), quartz ranges between 10.2 and 15.7 wt.\% (average 12.6 wt.\%) and feldspars range between 5.3 and 13.3 wt.\% (average 8.8 wt.\%). Chlorite is the most abundant clay mineral and ranges between 7.0 and $14.5 \mathrm{wt} . \%$ (average $10.1 \mathrm{wt} . \%$ ), illite ranges between 3.2 and 11.4 wt.\% (average 7.8 wt.\%), kaolinite ranges between 3.2 and $7.2 \mathrm{wt} . \%$ (average $5.1 \mathrm{wt} . \%$ ), smectite ranges between 0.5 and 7.1 wt.\% (average 3.0 wt.\%) and palygorskite ranges between 1.4 and $3.3 \mathrm{wt} . \%$ (average $2.0 \mathrm{wt} . \%$ ). The biogenic component of the sediments is composed mainly of calcite, $\mathrm{Mg}$-calcite and aragonite. In the sediments, hornblende ranges between 2.5 and 5.5 wt.\% (average 3.7 wt.\%), and it occurs together with serpentine and talc as accessory mineral phases, indicating input from an ultrabasic component, while pyrite is a trace phase. The main phases in the sediment samples comprise 


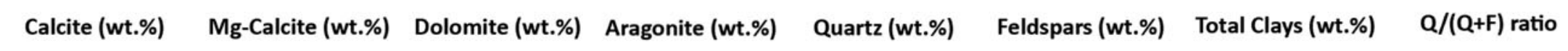
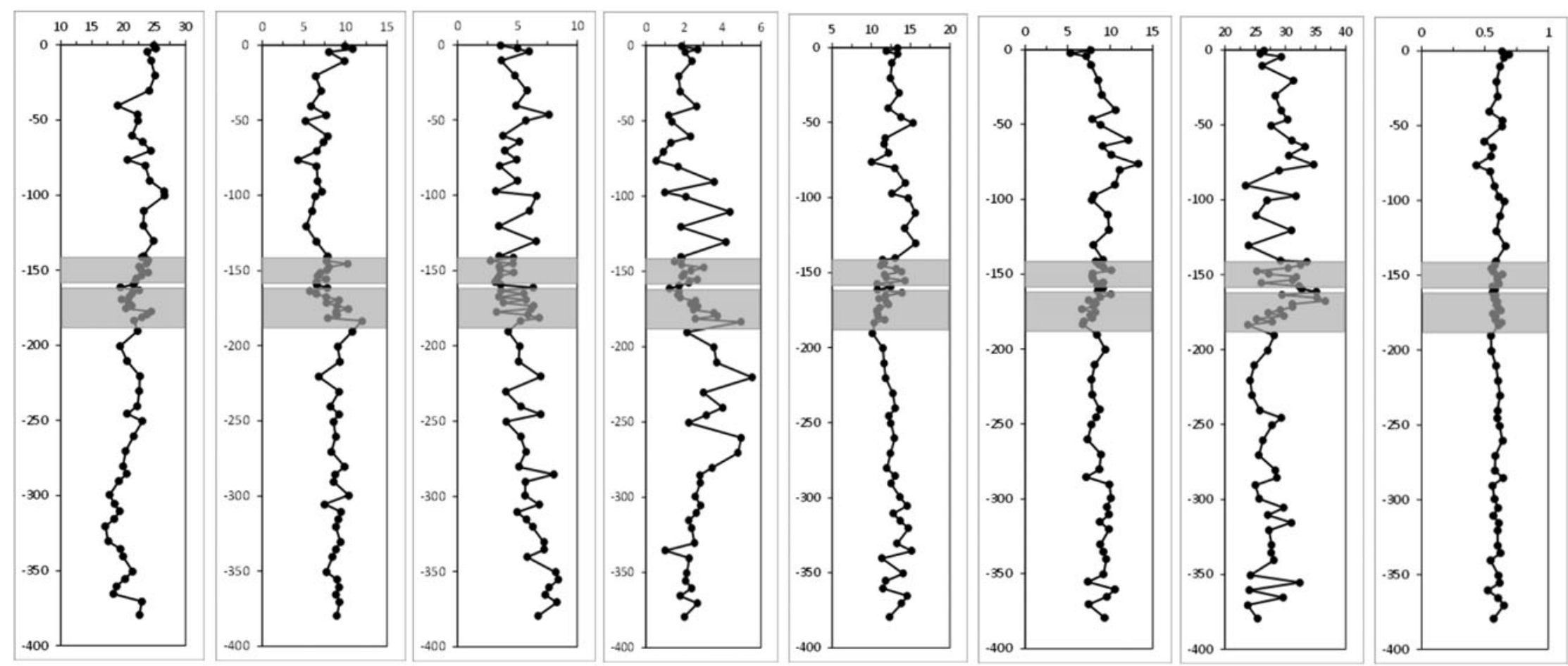

Fig. 3. Downcore variation of major minerals (wt.\%) in core ST5 determined using the Rietveld method. The shaded areas indicate sapropel S1. The vertical axes denote the depth bsf. 
Table 1. Mineralogical composition of core ST5.

\begin{tabular}{|c|c|c|c|c|c|c|c|c|c|c|c|c|}
\hline \multirow[b]{2}{*}{ Minerals } & \multicolumn{4}{|c|}{ Holocene sediments above sapropel S1 } & \multicolumn{4}{|c|}{ Sapropel S1 } & \multicolumn{4}{|c|}{ Holocene sediments below sapropel S1 } \\
\hline & Mean (wt.\%) & SD & Min. (wt.\%) & Max. (wt.\%) & Mean (wt.\%) & SD & Min. (wt.\%) & Max. (wt.\%) & Mean (wt.\%) & SD & Min. (wt.\%) & Max. (wt.\%) \\
\hline Calcite & 23.8 & 1.7 & 19.1 & 26.6 & 22.2 & 1.4 & 19.6 & 24.5 & 20.6 & 1.9 & 17.2 & 23.1 \\
\hline Mg-calcite & 7.2 & 1.7 & 5.2 & 10.9 & 8.1 & 1.5 & 5.7 & 12.0 & 9.0 & 0.9 & 6.8 & 10.8 \\
\hline Dolomite & 4.8 & 1.1 & 3.5 & 6.6 & 4.5 & 1.3 & 2.8 & 6.8 & 5.9 & 1.3 & 4.0 & 8.3 \\
\hline Aragonite & 2.3 & 1.0 & 0.9 & 4.4 & 2.4 & 0.9 & 1.2 & 5.0 & 3.1 & 1.0 & 2.0 & 5.6 \\
\hline Palygorskite & 2.0 & 0.5 & 1.4 & 3.3 & 2.3 & 0.4 & 1.6 & 3.1 & 1.8 & 0.2 & 1.4 & 2.3 \\
\hline Smectite & 3.7 & 0.9 & 1.8 & 4.9 & 3.9 & 1.4 & 1.6 & 7.1 & 1.5 & 0.7 & 0.5 & 3.5 \\
\hline Kaolinite & 5.0 & 0.8 & 3.2 & 6.3 & 5.1 & 0.8 & 4.0 & 7.2 & 5.1 & 0.4 & 3.9 & 5.7 \\
\hline Chlorite & 9.9 & 2.3 & 7.0 & 14.5 & 9.8 & 1.9 & 7.1 & 12.4 & 10.5 & 1.6 & 7.2 & 13.0 \\
\hline Illite & 7.4 & 1.7 & 3.2 & 9.8 & 9.1 & 1.4 & 6.3 & 11.4 & 7.0 & 0.8 & 5.7 & 8.9 \\
\hline Hornblende & 3.5 & 0.4 & 2.9 & 4.1 & 4.2 & 0.7 & 3.2 & 5.5 & 3.3 & 0.4 & 2.5 & 4.4 \\
\hline Quartz & 13.5 & 1.3 & 11.8 & 15.7 & 11.8 & 1.1 & 10.4 & 14.3 & 12.5 & 1.1 & 10.2 & 14.7 \\
\hline Plagioclase & 5.7 & 1.2 & 2.8 & 7.3 & 5.0 & 0.6 & 4.0 & 6.0 & 5.8 & 0.8 & 4.1 & 7.0 \\
\hline Orthoclase & 3.4 & 0.7 & 2.3 & 5.2 & 3.3 & 0.9 & 2.5 & 4.1 & 3.1 & 0.6 & 1.8 & 4.0 \\
\hline Paragonite & 4.7 & 0.7 & 3.3 & 6.3 & 5.5 & 1.0 & 4.2 & 8.0 & 5.3 & 0.7 & 4.2 & 7.3 \\
\hline Lizardite & 2.9 & 1.4 & 0.7 & 5.3 & 2.5 & 1.4 & 0.6 & 4.5 & 4.5 & 1.3 & 2.2 & 6.5 \\
\hline $\mathrm{Q} / \mathrm{Q}+\mathrm{F}$ & 0.60 & 0.05 & 0.49 & 0.69 & 0.59 & 0.02 & 0.55 & 0.64 & 0.59 & 0.03 & 0.52 & 0.65 \\
\hline
\end{tabular}

quartz and feldspars, accessory minerals from the ultrabasic component and clay minerals. Compared with the sediments that were studied by Leontopoulou et al. (2019), core ST5 displays three main differences (cf. Table 1 of this study with table 2 in Leontopoulou et al., 2019): (1) it has considerably lower $\mathrm{Mg}$ calcite and total carbonate contents but considerably greater dolomite contents; (2) it contains more chlorite, hornblende and serpentine, which underlines the contribution of an ultrabasic component, probably from the west Anatolian mainland; and (3) it has greater total clay mineral contents and quartz/ (quartz + feldspar) $(\mathrm{Q} / \mathrm{Q}+\mathrm{F})$ ratios.

The abundances of the various minerals display varying trends with increasing depth (Fig. 3). The abundances of dolomite and $\mathrm{Mg}$-calcite tend to increase downcore, while that of calcite follows the opposite trend and that of aragonite remains constant in general throughout the core. The abundance of quartz tends to increase until the top of S1, then it decreases until the bottom of $\mathrm{S} 1$, where it reaches a minimum, and then it increases again at greater depths towards the bottom of the core. On average, the abundance of feldspars is generally constant throughout the core, whereas that of total clay minerals is constant on average in pre-sapropel S1 sediments, increases within sapropel S1 and remains generally constant in the post-sapropel S1 sediments (Fig. 3).

Serpentine displays a statistically significant overall positive correlation with chlorite ( $r=0.72$; Fig. $4 \mathrm{a})$. This suggests the possibility for a common source and/or similar sedimentation processes for the two minerals. Two main subparallel trends are observed (Fig. 4): one for the pre-sapropel samples and a second one for the sapropel and post-sapropel sediments. In addition, the sediments from the upper sapropel horizon are generally richer in serpentine compared with their lower sapropelic counterparts. Moreover, a statistically significant overall negative correlation is observed between serpentine and illite $(r=-0.72$; Fig. $4 \mathrm{~b})$ and between chlorite and dolomite ( $r=-0.84$ and -0.73 ; Fig. $4 c)$. In the latter diagram two subparallel negative trends are observed, with the pre-sapropel S1 sediments having greater dolomite contents (Fig. 4c). Finally, clay minerals are inversely correlated with carbonates (Fig. 5a). The sapropelic sediments in general are richer in clay minerals than carbonates compared to the nonorganic sediments. By contrast, the sapropelic sediments contain generally less quartz than their non-organic counterparts.
Furthermore, except for the S1 horizon, no particular trend is observed between clay minerals and quartz (Fig. 5b).

\section{Clay mineralogy}

The downcore distribution of clay minerals is depicted in Fig. 6, while the whole quantitative clay mineralogical dataset is listed in Table S2. An important characteristic of core ST5 compared to most Aegean areas is the presence of chlorite as the most abundant phyllosilicate (average $10.1 \mathrm{wt} . \%)$. The abundance of chlorite does not display a clear trend with depth. It is worth noting that illite and chlorite have a strong negative relationship, so in samples with large contents of illite there are small amounts of chlorite and vice versa. This is observed in almost the entire distribution of the core, except for the sapropel sequence, where this is less pronounced. Another noticeable feature of core ST5 is the lack of significant variations in the clay mineralogy of the sapropel horizon compared to the remaining sections of core ST5 (Fig. 6). The sediments in the south-west Aegean Sea and the Cretan Sea display a significant increase in illite and total clay mineral contents and, to a lesser degree, of smectite and kaolinite in the S1a and S1b horizons (Leontopoulou et al., 2019).

The greater chlorite contents in the south-east Aegean Sea are attributed principally to supply from the widespread occurrences of basic/ultrabasic rocks in the mainland of west Turkey and, to a lesser degree, in the surrounding islands (Aksu et al., 1995a; Ergin, 2012). Illite is the second most abundant mineral in core ST5 (average 7.8\% wt.\%), displaying lower abundances compared to the south-west Aegean Sea and the Cretan Sea (average 10.6 and $8.3 \mathrm{wt} . \%$, respectively). Smectite is also present generally in lesser amounts in core ST5 (average $3 \mathrm{wt} . \%$ ) compared to the south-west Aegean Sea and the Cretan Sea (3.8 wt.\% on average in both cores). Therefore, there is a decrease in the illite and smectite contents in the south-east Aegean Sea sediments compared to their counterparts from the Cretan Sea and the southwest Aegean Sea. Similarly, the average kaolinite content is slightly lower in core ST5 (average $5.1 \mathrm{wt}$ \%) compared to the south-west Aegean Sea and the Cretan Sea (average 5.4 and 5.7 wt.\%, respectively) (Leontopoulou et al., 2019). The presence of palygorskite is indicative of aeolian input in the Aegean, although terrestrial input might also be possible (Chamley, 1989), considering that the broader area of west Anatolia is characterized by alkaline, 
Table 2. Correlation coefficient (Pearson's $r$ ) matrix of the major and trace elements in core ST5. Numbers in bold indicate $r$ values $>0.7$.

\begin{tabular}{|c|c|c|c|c|c|c|c|c|c|c|c|c|c|c|c|c|c|c|c|c|c|c|c|c|c|c|c|}
\hline & $\mathrm{SiO}_{2}$ & $\mathrm{TiO}_{2}$ & $\mathrm{I}_{2} \mathrm{O}_{3}$ & ${ }_{2} \mathrm{O}_{3}$ & no & MgO & $\mathrm{aO}$ & $\mathrm{a}_{2} \mathrm{O}$ & $\mathrm{K}_{2} \mathrm{O}$ & $\mathrm{P}_{2} \mathrm{O}_{5}$ & LOI & v & $\mathrm{Cr}$ & 0 & $\mathrm{Ni}$ & $\mathrm{Cu}$ & $\mathrm{Zn}$ & $\mathrm{b}$ & $\mathrm{Sr}$ & $Y$ & $\mathrm{Zr}$ & $\mathrm{Ba}$ & a & $\mathrm{Ce}$ & $\mathrm{Jd}$ & b & Th \\
\hline$b_{2}$ & 1 & 0.745 & & 39 & & & & 686 & & & & & & & & & & & & & & & & & & 81 & \\
\hline 2 & 0.745 & 1 & & .241 & 301 & -0.528 & & & 742 & & & & & & & & 38 & & & 0.673 & 0.749 & & 47 & 72 & 159 & 334 & 467 \\
\hline $\mathrm{O}_{3}$ & 0.807 & 0.798 & 1 & 0.677 & 0.107 & -0.578 & -0.651 & 336 & 0.982 & & -0.552 & 0.401 & -0.732 & 46 & & 0 & 0.903 & 0.966 & -0.700 & 0.811 & 0.423 & 00 & .543 & 0.228 & 0.408 & 0.470 & 0.473 \\
\hline${ }_{2} \mathrm{O}_{3}$ & 0.639 & 241 & & 1 & .346 & -0.120 & & & & & & & -0.435 & & & 666 & .785 & & & 0.600 & & & 128 & & .024 & & \\
\hline ( & -0.088 & 301 & & -0.346 & 1 & -0.480 & 58 & & 0.032 & 79 & 0.077 & $-c$ & 300 & -0.275 & -0.588 & 0.069 & -0.039 & 23 & & 0.212 & 83 & & & & 243 & & .262 \\
\hline 50 & -0.151 & -0.528 & - & -0.120 & - & 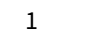 & & 2 & -0.554 & -0.567 & & -0 & & & & -0.424 & -0 & -0 & 22 & -0 & -0.249 & & & -0.513 & -0.578 & -0.635 & -0.3 \\
\hline 0 & -0.585 & 311 & -0.651 & 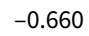 & & & 1 & & -0.691 & -0.086 & & -1 & & & -1 & -0 & 0.662 & & & & & & & & 72 & & \\
\hline 0 & & & & & & & -4 & & & & & & & & & & & & & & & & & & & & \\
\hline 0 & 0.807 & 0.742 & & & 0.032 & -0.554 & -0 & & 1 & & -0.566 & & & & & & 25 & & & 99 & & & 09 & 09 & 96 & 120 & 410 \\
\hline $\mathrm{O}_{5}$ & y & & & & & -0 . & -0. & & & & -0.4 & & 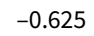 & & -0 & 51 & & & -0 & & & & & & 65 & 18 & \\
\hline & -0.806 & .520 & .552 & -0.629 & & & & & 66 & 56 & 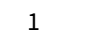 & 0.391 & & & -0.293 & .456 & 663 & & & 6 & & & & & & & \\
\hline & & 0.090 & & & -0.164 & -0 & & & & & & & & & & & & & & & & & & & & & \\
\hline & -0 & -0.457 & -0.732 & -0 & - & & & & -0. & -0 . & & -0. & & & & -0 & 9 & -0 & & -0 & -0 & -0 & & & & & \\
\hline & & & & & & & -0 & & & & & & & & & & & & & & & & & & & & \\
\hline & & -0 & - & & & & & & - & & & & & & & & & & & & & & & & & & \\
\hline & & & & & & & & & & & & & & & & & & & & & & & & & & & \\
\hline$n$ & & & & & 9 & & -0 & & & & & & & & & & & 3 & & & & & & & 69 & 01 & \\
\hline b & & & & & & & -0 . & & & & -0 & & & & & & & & -0 & & & & & & 45 & 344 & 0.393 \\
\hline & & -0.710 & -0 & & & & & & -0.689 & -0 & & & & & & & & & 1 & -0.4 & & & & & & & \\
\hline & & & & & & & & & & & & & 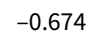 & & & & & & & & - & & & & & 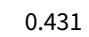 & \\
\hline 1 & 0.544 & 0.749 & 3 & -0.051 & & -0.249 & & 02 & 0. & & -0.408 & -0.264 & 229 & -0.187 & -0.381 & -0.046 & 33 & & & & & -0.387 & 452 & .381 & .237 & 607 & .454 \\
\hline & & ror & & & & & & & & & & & & & & & & & & & & & -0.2 & & & & \\
\hline & & & & & & & & & & & & & & & & & & & & & & & & 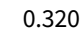 & & & \\
\hline & 8 & 0.47 & 88 & -0.196 & & -0. & & & 0. & & -0.174 & & & -0.292 & -0 & & & & & & 81 & & 20 & 1 & 0.489 & 0.544 & .201 \\
\hline & & & & & & & & & & & & & & & & & & & & & & & & & & 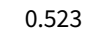 & \\
\hline & & & & & & & & & & & & & & & & & & & & & & & & & & & \\
\hline $\mathrm{h}$ & 0.226 & 0.467 & 0.473 & 0.093 & 0.262 & -0.390 & -0.208 & -0.063 & 0.410 & 0.160 & -0.059 & -0.066 & -0.477 & -0.067 & -0.285 & 0.333 & 0.256 & 0.393 & -0.295 & 0.459 & 0.454 & -0.105 & 0.126 & 0.20 & -0.008 & 0.322 & 1 \\
\hline
\end{tabular}



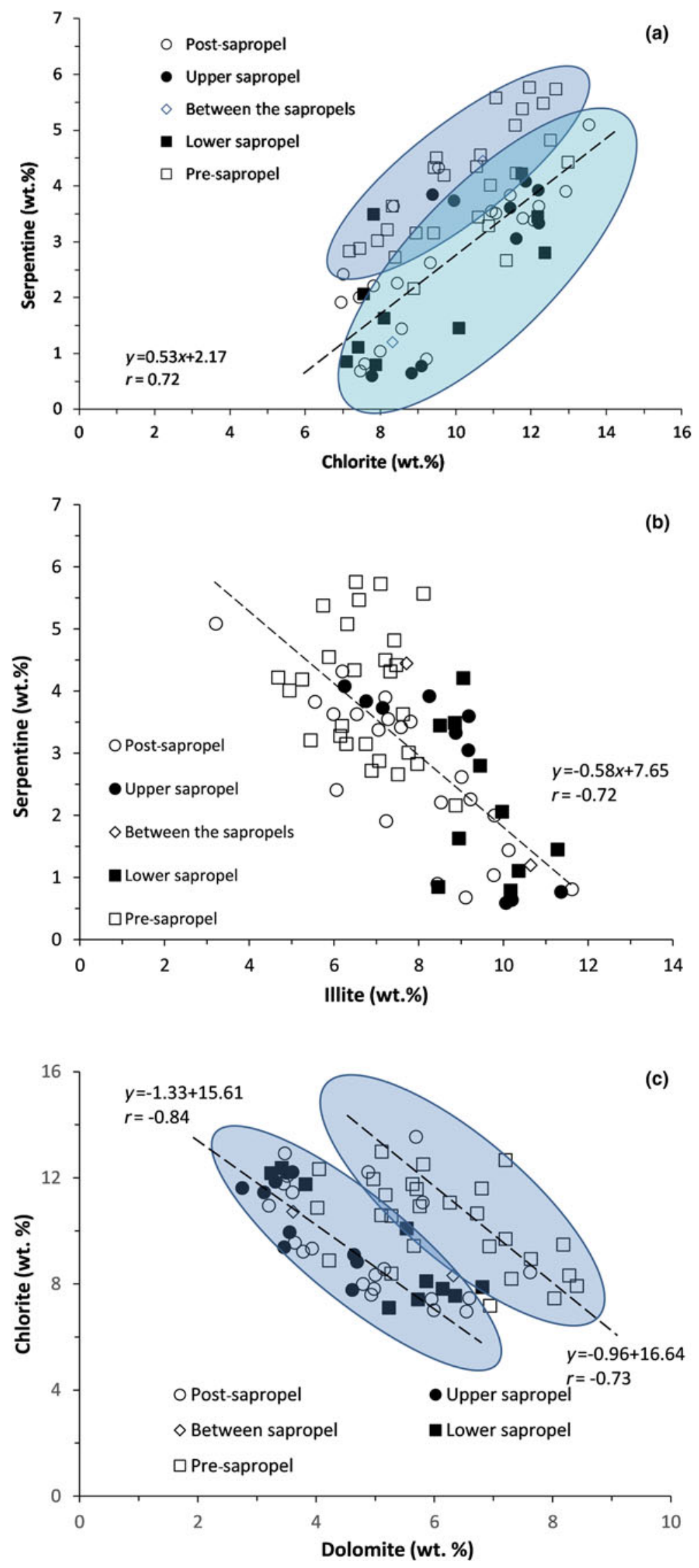

Fig. 4. (a) Serpentine vs chlorite, (b) serpentine vs illite and (c) chlorite vs dolomite in the ST5 sediments. The two shaded areas indicate the two groups of samples displaying subparallel trends. See text for discussion. 

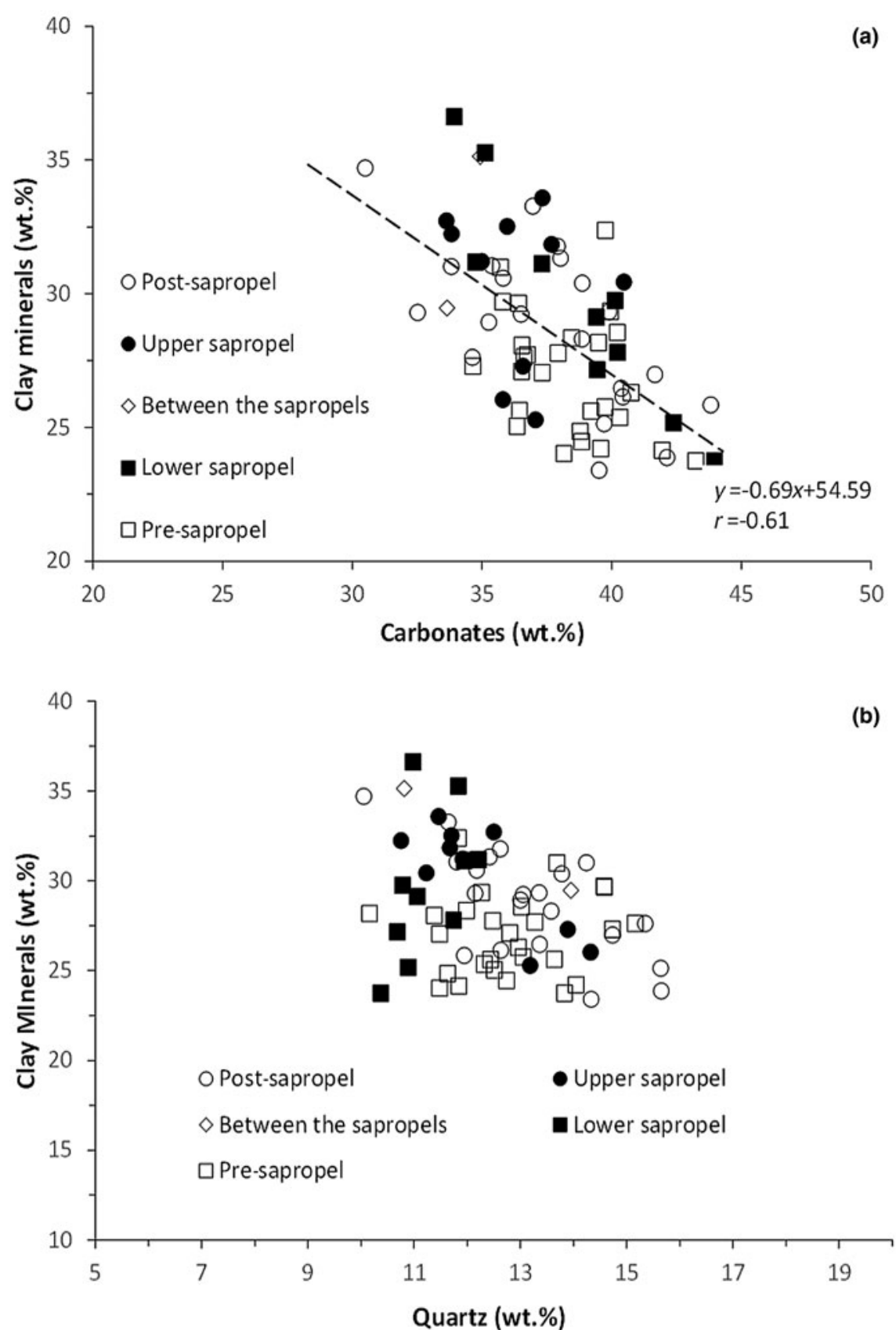

Fig. 5. Clay minerals vs (a) total carbonates and (b) quartz.

Quartz (wt.\%)

palygorskite-bearing soils (Kadir et al., 2014). The palygorskite content in core ST5 (average 2 wt.\%) is slightly smaller than those of the Cretan Sea (average 2.4 wt.\%) and the south-west Aegean Sea (average $2.2 \mathrm{wt} . \%$ ). Although several of the differences in the average abundances of clay minerals are within the uncertainty bounds of the analytical method, they refer to average values over large sets of samples in each core, suggesting that they are statistically significant.

Slight increases in the illite and total clay contents are also observed in core ST5, which are less pronounced compared to in the south-west Aegean Sea and the Cretan Sea (e.g. compare Fig. 6 \& Table S1 with Leontopoulou et al., 2019). By contrast, in core ST5 the smectite content increases gradually from the base of the sapropel horizon upwards, without particular enrichment in the sapropel horizon (Fig. 6). Finally, the illite/kaolinite
$(\mathrm{I} / \mathrm{K})$ and smectite/kaolinite $(\mathrm{S} / \mathrm{K})$ ratios increase gradually towards the top (Fig. 7), a trend that is more apparent for the $\mathrm{S} / \mathrm{K}$ ratio. The illite/chlorite and chlorite/kaolinite ratios do not display any particular trends with depth (data not shown).

After heating of the clay fractions at $530^{\circ} \mathrm{C}$ and subsequent EG solvation the smectite remained essentially unaffected, as is indicated by the position of the 001 diffraction maximum at $\sim 17 \AA$, although the intensity of the maximum decreased, especially in the pre-sapropel sediments (Fig. S2). This feature suggests that a significant fraction of the smectite has a high dehydroxylation temperature, indicating a cis-vacant octahedral occupancy (Drits et al., 1998). The decrease in intensity of the 001 maximum, especially in the pre-sapropel sediments, indicates that trans-vacant smectite might also be present, which may predominate in the pre-sapropel sediments. In comparison, the smectites in the 


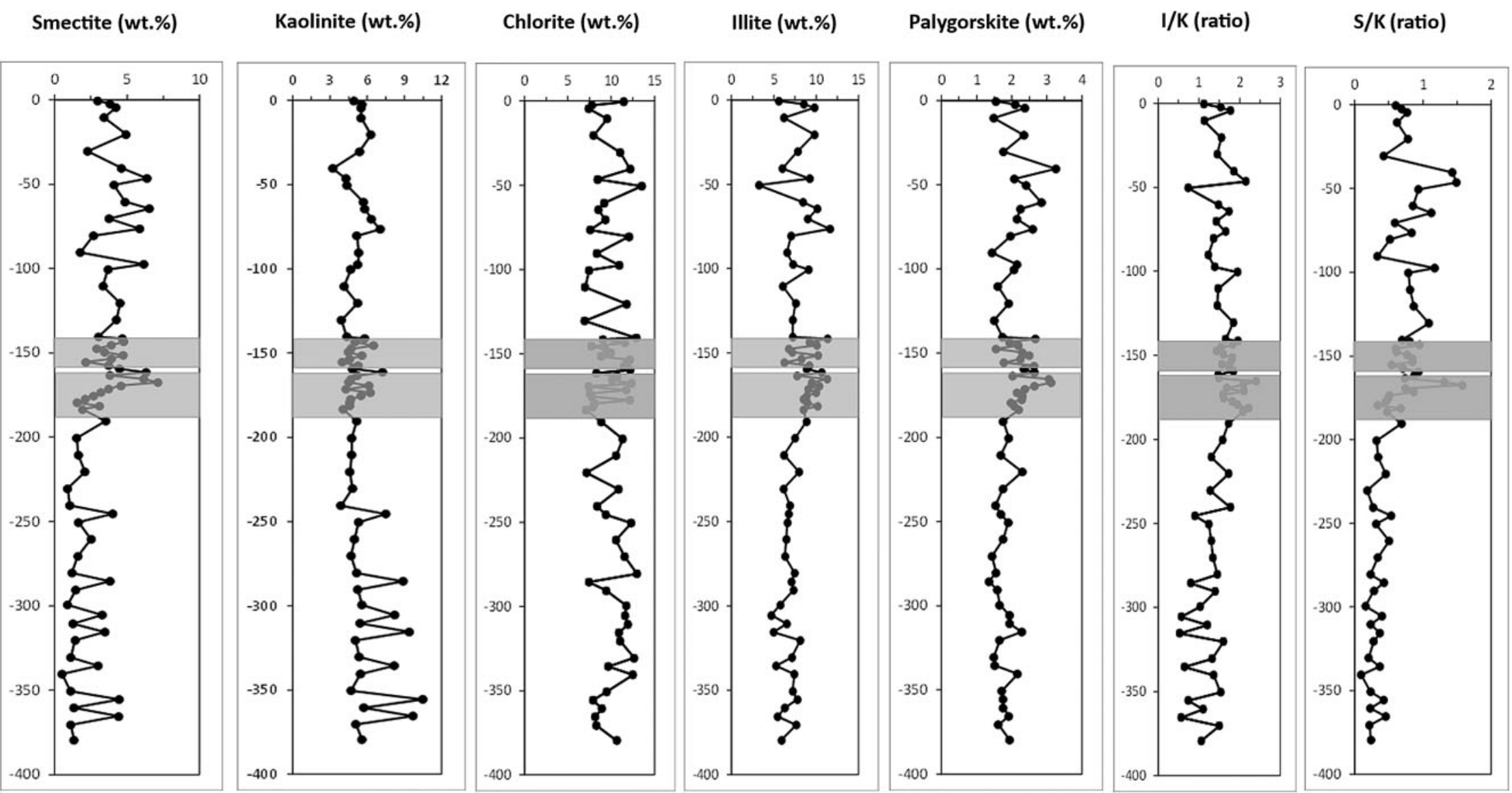

Fig. 6. Downcore variation of clay minerals (wt.\%) and $\mathrm{I} / \mathrm{K}$ and $\mathrm{S} / \mathrm{K}$ ratios in core ST5 determined using the Rietveld method. The shaded areas indicate sapropel S1. The vertical axes denote the depth bsf. 


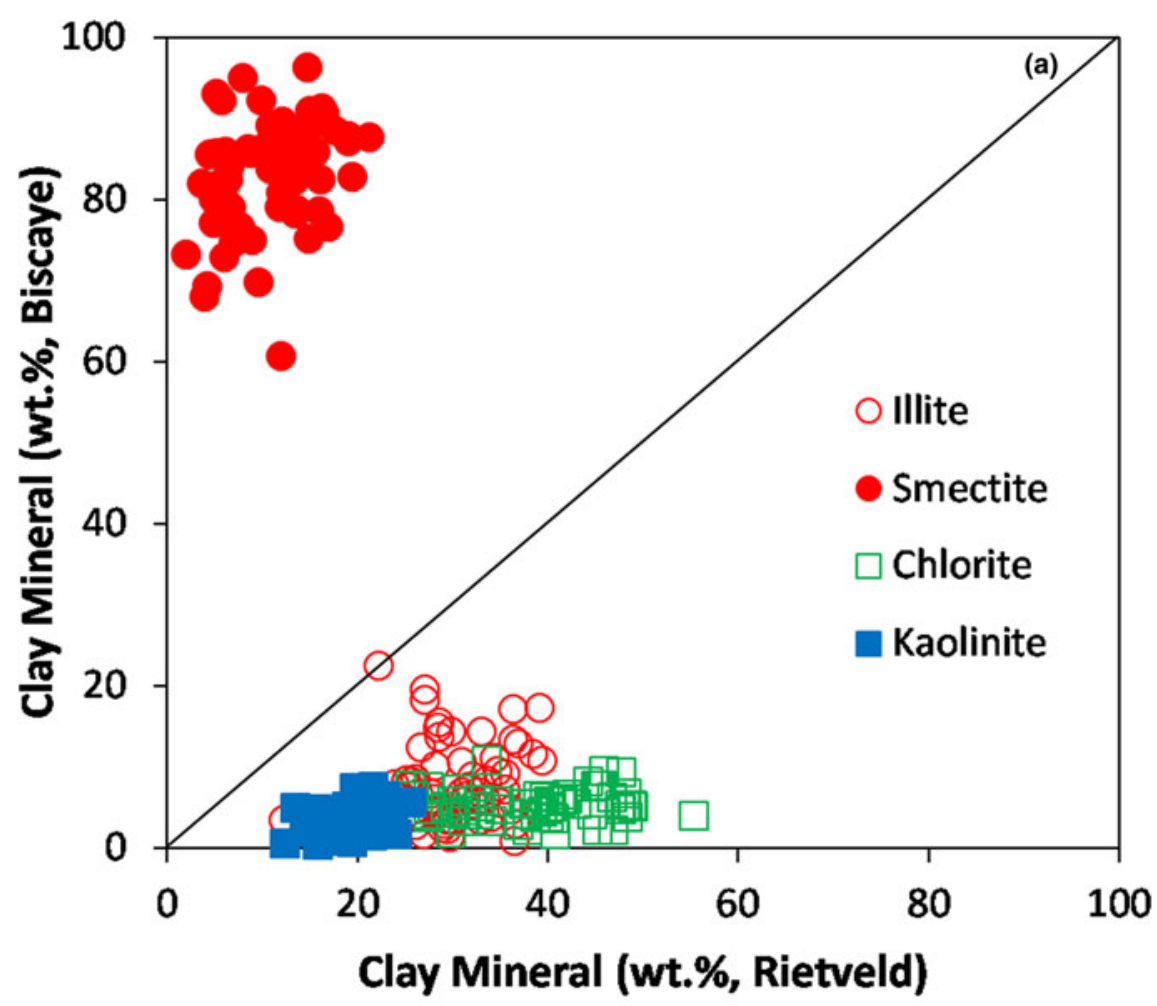

Fig. 7. (a) Correlation between the clay mineral contents determined using Rietveld refinement of the bulk sediments and the method of Biscaye (1965) in the clay fractions. (b) Smectite vs illite trends obtained from the Biscaye method (open circles) and the Rietveld method (inset). See text for discussion.

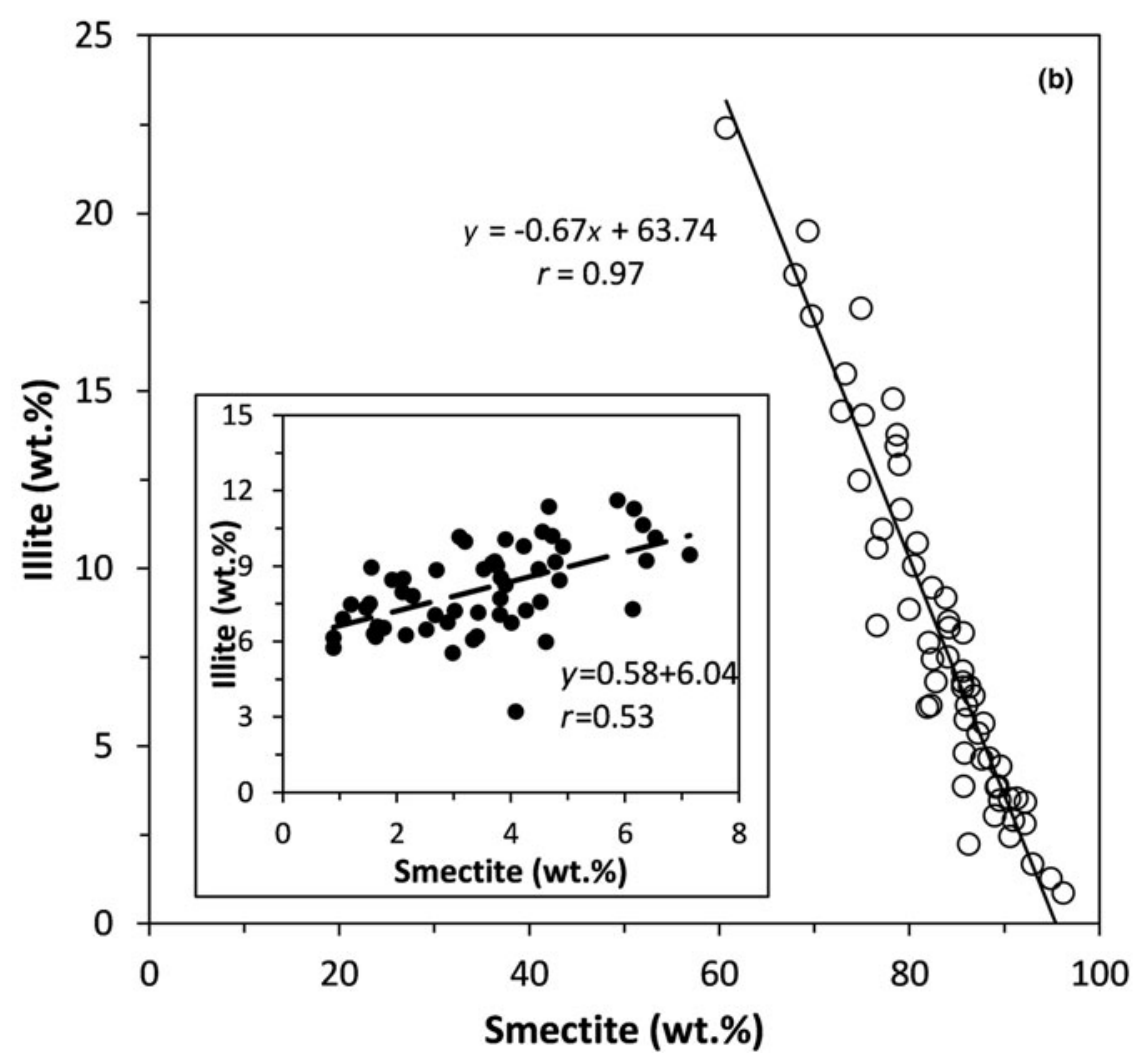

Cretan Sea displayed cis-vacant behaviour, whereas the smectites in the south-west Aegean Sea displayed trans-vacant behaviour characterized by low dehydroxylation temperatures (Leontopoulou et al., 2019). In the clay fraction, abundant serpentine occurred as an additional $7 \AA$ phase, as well as kaolinite, chlorite, carbonates (mainly calcite and Mg-calcite) and quartz, while traces of palygorskite were detected only in a few samples. Dolomite occurred mainly in the silt and sand fractions.

The abundances of the four clay minerals determined using the Rietveld method normalized to $100 \%$ and their counterparts 
determined using the method proposed by Biscaye (1965) are listed in Table S3. A comparison of the abundances of the individual clay minerals determined using the two methods clearly indicates an underestimation of smectite and an overestimation of the remaining clay minerals in the former approach compared to the latter (Fig. 7a). A similar trend was observed in the south-west Aegean Sea and the Cretan Sea, except for the fact that the illite content was comparable when using the two methods (Leontopoulou et al., 2019). As a portion of the chlorite and illite (mica) crystals will be coarser than $2 \mu \mathrm{m}$, the use of only the clay fraction is not reliable for complete palaeogeographical and/or palaeoclimatic interpretations and does not provide complete information about weathering mechanisms in the source areas. The overestimation of smectite when using the method proposed by Biscaye (1965) is due to the fine particle size of smectite crystallites that settle after the remaining clay minerals, causing a 'smearing effect' (Leontopoulou et al., 2019). This is a potential reason as to why minor clay minerals such as palygorskite may not be identified in oriented mounts. The striking difference in the trend for illite underlines the influence of particle size on the quantitative determination of phyllosilicates using the various methods, and its ramifications for the sedimentation regime are addressed in the 'Discussion' section. In addition, the two methods yielded different trends between clay minerals. The Rietveld method yielded a weak positive correlation between smectite and illite $(r=0.53)$, whereas the method proposed by Biscaye yielded a very strong negative correlation between the two minerals $(r=-0.97$; Fig. 7b). Similar trends were reported by for the south-west Aegean Sea and the Cretan Sea (Leontopoulou et al., 2019).

Examination of the clay fractions using SEM demonstrated the presence of Emiliania huxleyi coccolithophore fragments and clay minerals (Fig. S3). In addition, fine-grained, well-crystallized calcite is present in most samples. Calcite is associated locally with pyrite. No dolomite was identified in the SEM micrographs, which is in accordance with the XRD results. The EDS analyses of the clay minerals demonstated the presence of mixtures of illite, smectite and chlorite. It was not possible to isolate crystals of individual clay minerals. Emiliania huxleyi is generally a main coccolithophore in the lower and upper euphotic zones of the Mediterranean. It predominates in the surface waters of the Aegean Sea, mainly in winter/spring, and it indicates greater values of $S$ and the beginning of a nutrient-rich euphotic zone (Triantaphyllou et al., 2009). In general, the abundance of coccolithophores decreases with depth. Moreover, the sapropel sediments display a significant decrease in coccolithophores, which is in accordance with the reduction in the $\mathrm{CaO}$ content in the geochemical analysis compared to the pre- and post-sapropel sediments.

\section{Geochemistry of core ST5}

Major elements. The downcore distribution of major elements is shown in Fig. 8a, while the geochemical data are listed in Table S4. The abundances of $\mathrm{SiO}_{2}, \mathrm{Al}_{2} \mathrm{O}_{3}, \mathrm{Fe}_{2} \mathrm{O}_{3}, \mathrm{Na}_{2} \mathrm{O}$ and $\mathrm{K}_{2} \mathrm{O}$ increase gradually upcore, decreasing in the uppermost 40 $\mathrm{cm}$. Moreover, with the exception of $\mathrm{Na}_{2} \mathrm{O}$, the sapropel S1 horizon is enriched in these elements compared to the sediments immediately before and after the sapropel. By contrast, $\mathrm{MgO}$ displays the opposite trend, decreasing gradually upcore. Again, the sapropel S1 horizon is enriched in $\mathrm{MgO}$ compared to the pre- and post-sapropel sediments. Finally, $\mathrm{CaO}$ does not display a clear overall trend throughout the core. Nevertheless, it decreases in post-sapropelic sediments up to $40 \mathrm{~cm}$ bsf, increasing thereafter. The $\mathrm{CaO}$ contents of the samples were calculated independently of the abundances of calcite, $\mathrm{Mg}$-calcite, aragonite and dolomite using the end-member compositions for calcite, aragonite and dolomite and considering the $10 \% \mathrm{Mg}$ mole in Mg-calcite. The calculated $\mathrm{CaO}$ contents were within $\pm 5 \%$ (relative error) of the $\mathrm{CaO}$ contents determined using XRF spectroscopy, suggesting that the carbonate abundances determined by the quantitative analysis are reliable. Considering that $\mathrm{SiO}_{2}, \mathrm{Al}_{2} \mathrm{O}_{3}, \mathrm{Fe}_{2} \mathrm{O}_{3}$ and $\mathrm{Na}_{2} \mathrm{O}$ are associated with the clastic component and $\mathrm{CaO}$ is associated mainly with the authigenic carbonate component in the sediments, it is evident that in post-sapropelic sediments the clastic component increases upwards up to $40 \mathrm{~cm}$ bsf and that the authigenic component increases in abundance in the uppermost layers.

The sediments in core ST5 have, on average, greater $\mathrm{SiO}_{2}$, $\mathrm{MgO}, \mathrm{Fe}_{2} \mathrm{O}_{3}$, and $\mathrm{TiO}_{2}$ contents and smaller $\mathrm{CaO}, \mathrm{Al}_{2} \mathrm{O}_{3}, \mathrm{Na}_{2} \mathrm{O}$ and $\mathrm{K}_{2} \mathrm{O}$ contents compared to their counterparts in the southwest Aegean Sea and the Cretan Sea (compare Fig. 8a and Table S4 with data in Leontopoulou et al., 2019). The elemental composition is in accordance with the mineralogical composition of the sediments, confirming the reliability of the quantitative mineralogical analysis. Thus, the greater $\mathrm{SiO}_{2}$ and $\mathrm{Fe}_{2} \mathrm{O}_{3}$ contents are due to the greater quartz and total clay mineral abundances. The greater $\mathrm{MgO}$ content in core ST5 compared to those of the south-west Aegean Sea and Cretan Sea sediments is due to the greater chlorite, serpentine and dolomite contents in the former, because the Mg-calcite content is smaller in core ST5 compared to sediments in the south-west Aegean Sea and the Cretan Sea. The overall large $\mathrm{CaO}$ contents are related to the abundance of carbonates in the sediments (Fig. 8a). The smaller $\mathrm{CaO}$ content in core ST5 sediments than their counterparts in the south-west Aegean Sea and the Cretan Sea is in accordance with a smaller carbonate content in the former. Similarly, the smaller $\mathrm{Na}_{2} \mathrm{O}$ and $\mathrm{K}_{2} \mathrm{O}$ contents in core ST5 are in full accordance with the smaller feldspar and illite contents when compared to those of the south-west Aegean Sea and Cretan Sea sediments.

The Chemical Index of Alteration (CIA) values of the sediments (Nesbitt \& Young, 1982), are shown in Fig. 8a. The CaO content was omitted from the calculations because of the large abundance of carbonates in the samples. The CIA has been used as an efficient indicator of the intensity of weathering and subsequently as a palaeoclimatic proxy (Nesbitt \& Young, 1982; Meunier et al., 2013). The CIA ranges from 70 to 76 in core ST5 and averages $\sim 73$ (Fig. 9a). Such values are comparable with the average shale composition (Nesbitt \& Young, 1982) and are greater than the corresponding values for the south-west Aegean Sea and Cretan Sea sediments. In addition, the CIA displays a slight, gradual increase with decreasing depth (Fig. 8a). When $\mathrm{MgO}$ was included in the calculation of the CIA, after correction for the $\mathrm{Mg}$ present in $\mathrm{Mg}$-calcite and dolomite, the $\mathrm{CIA}_{(\mathrm{Mg})}$ index displayed a well-defined increase with decreasing depth (Fig. 8a). The sapropel S1 sediments have greater $\mathrm{CIA}_{(\mathrm{Mg})}$ indices than their counterparts in pre- and post-sapropel S1 sediments.

The $\mathrm{Al}_{2} \mathrm{O}_{3} / \mathrm{TiO}_{2}$ ratio of the sediments in core ST5 varies between 13.8 and 19.2 with an average value of 17.2 (Fig. $8 \mathrm{a}$ ), being smaller than those reported in the south-west Aegean Sea (average $\mathrm{Al}_{2} \mathrm{O}_{3} / \mathrm{TiO}_{2}$ ratio $=21.1$ ) and Cretan Sea sediments (average $\mathrm{Al}_{2} \mathrm{O}_{3} / \mathrm{TiO}_{2}$ ratio = 19.1) (Leontopoulou et al., 2019). The sediments of sapropel S1 have greater ratios than their in 
(a)
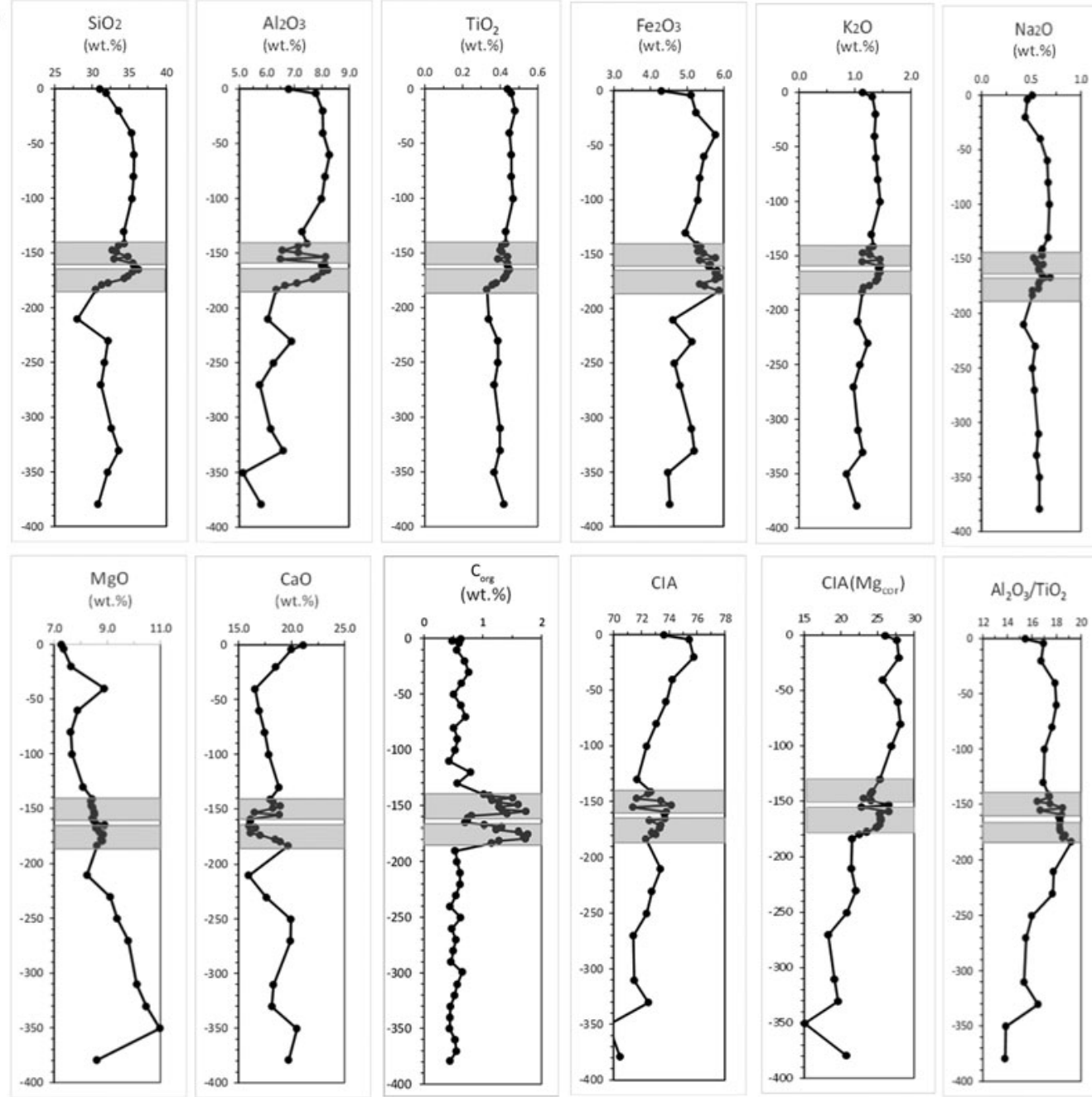

(b)
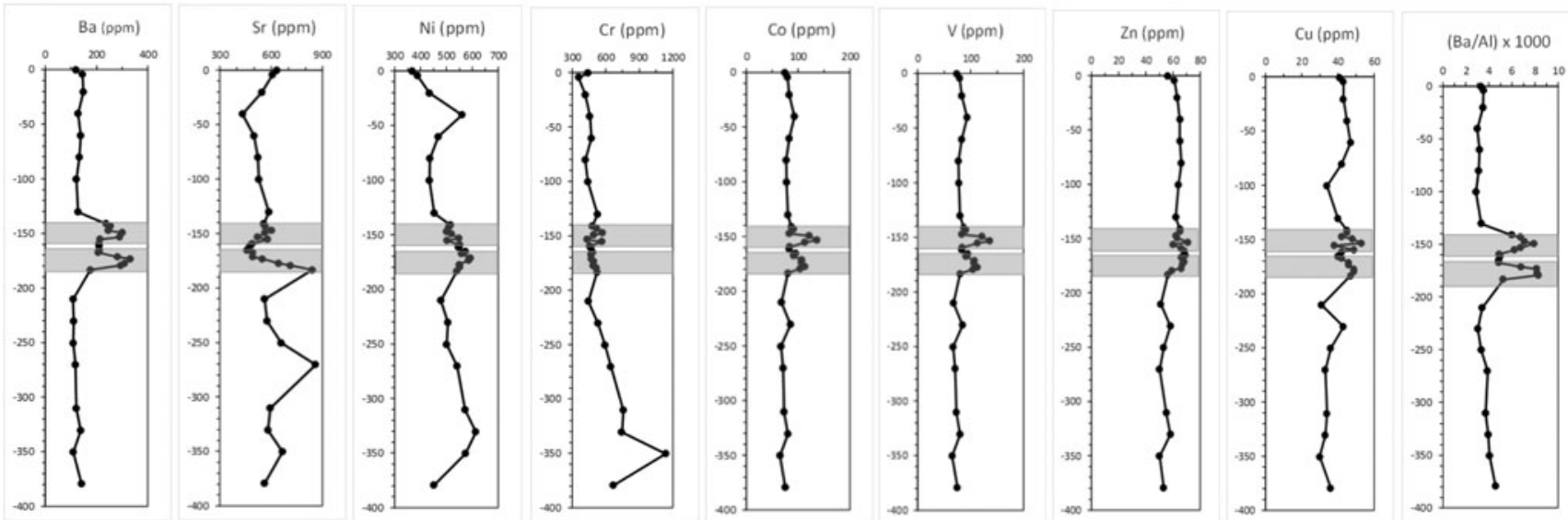

Fig. 8. Downcore variation of (a) major elements and (b) trace elements along core ST5. The shaded areas indicate sapropel S1. The vertical axes denote the depth bsf.

pre- and post-sapropel $\mathrm{S} 1$ counterparts. The $\mathrm{Al}_{2} \mathrm{O}_{3} / \mathrm{TiO}_{2}$ ratio is frequently used as a palaeoclimatic proxy (Kiipli et al., 2012). Values $<20$ are typically considered to be indicative of a humid climate and those between 20 and 30 are typically considered to be indicative of semi-humid/semi-arid climates in the sediment source areas. Large $\mathrm{Ti} / \mathrm{Al}$ ratios have been used as a proxy for increasing aeolian input in recent Central Mediterranean sediments (Bout-Roumazeilles et al., 2013).

Trace elements. $\mathrm{Ba}, \mathrm{Ni}, \mathrm{Co}$ and $\mathrm{V}$ are enriched in the sapropel $\mathrm{S} 1$ sediments compared to the remaining core sediments (Fig. $8 \mathrm{~b}$ ). Barium in marine sediments is typically hosted in marine barite $\left(\mathrm{BaSO}_{4}\right)$ and is associated with organic matter (Karageorgis 

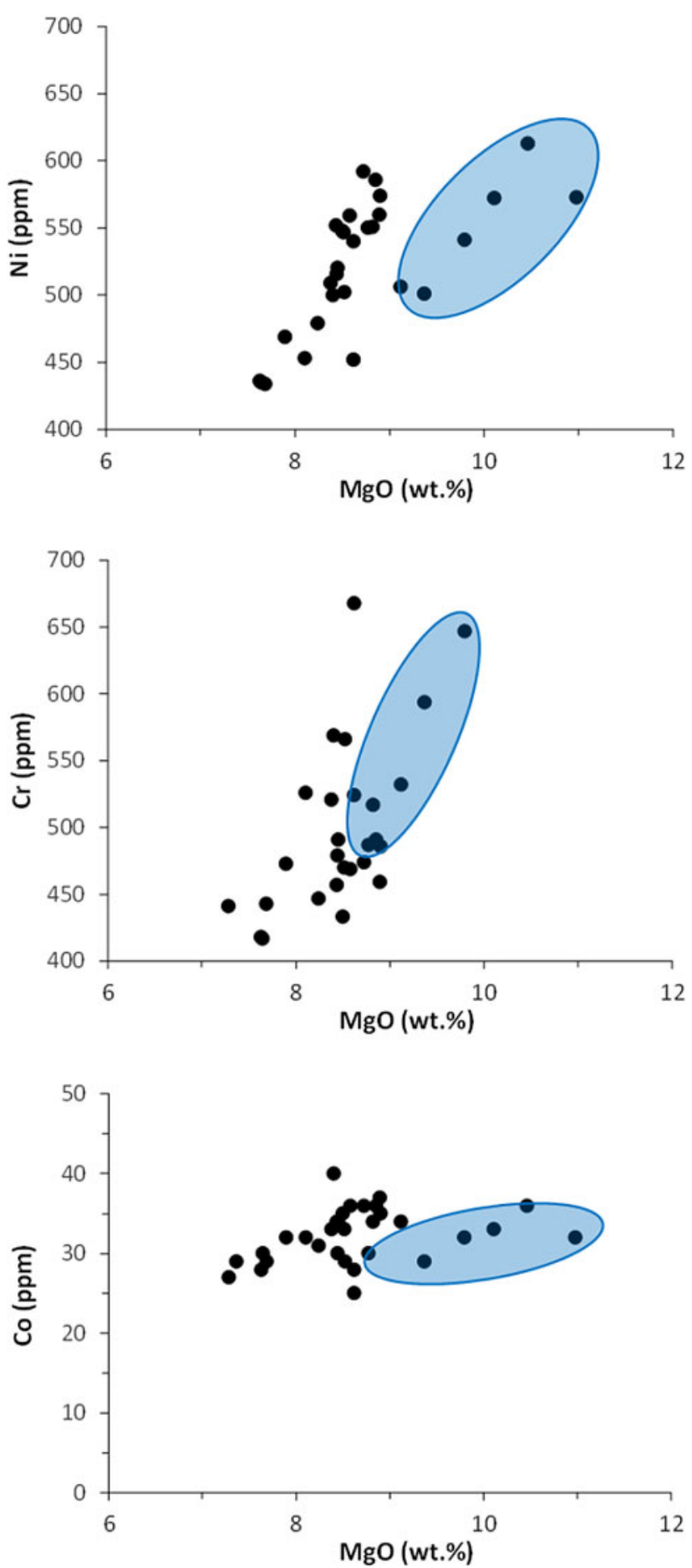

Fig. 9. $\mathrm{MgO}$ vs $\mathrm{Ni}, \mathrm{Cr}$ and $\mathrm{Co}$. The shaded areas indicate samples from the lowermost section of the core.

et al., 2005). All sapropel sediments are enriched in $\mathrm{Ba}$, as is indicated by the $\mathrm{Ba} / \mathrm{Al}$ ratio (Fig. $8 \mathrm{~b}$ ). Increased contents of $\mathrm{Ba}$ in sediments rich in organic matter are considered to represent a reliable palaeoproductivity proxy for this environment (Van Santvoort et al., 1996; Thomson et al., 1999; Martinez-Ruiz et al., 2000; Filippidi et al., 2016). The abundances of $\mathrm{Zn}$ and $\mathrm{Cu}$ increase from the bottom of sapropel S1 upwards, being lower in the pre-sapropelic sediments. $\mathrm{Cr}$ and Ni decrease gradually upwards following the distribution of $\mathrm{MgO}$ (Fig. 8a).
Indeed, $\mathrm{MgO}$ shows clear positive trends with $\mathrm{Cr}, \mathrm{Ni}$ and $\mathrm{Co}$ (Fig. 9). Samples from the lowermost section of the core follow a different linear trend characterized by greater $\mathrm{MgO}$ contents (Fig. 9). By contrast, $\mathrm{Zn}$ and $\mathrm{Rb}$ and, to a lesser degree, $\mathrm{Cu}$ (Fig. 8b) follow the opposite trend, increasing upwards (i.e. they display similar distributions to $\mathrm{SiO}_{2}, \mathrm{Al}_{2} \mathrm{O}_{3}, \mathrm{Fe}_{2} \mathrm{O}_{3}, \mathrm{Na}_{2} \mathrm{O}$ and $\mathrm{K}_{2} \mathrm{O}$; Fig. 8a). The trend for $\mathrm{Cu}$ may reflect the lower precision of the analytical method at low concentrations of $\mathrm{Cu}$ (Georgakopoulou et al., 2017).

The Pearson correlation coefficients $(r)$ between major and trace elements are listed in Table 2. Pearson's correlation coefficient values $>0.7$ indicate very good correlations and are highlighted in bold. The chemical elements that display very good correlation can be separated into three different groups, indicating at least two distinct clastic sources and certain geochemical/mineralogical processes. The first group, indicating a clastic source, includes incompatible elements of crustal affinities $\left(\mathrm{SiO}_{2}, \mathrm{Al}_{2} \mathrm{O}_{3}\right.$, $\mathrm{TiO}_{2}, \mathrm{~K}_{2} \mathrm{O}, \mathrm{Rb}, \mathrm{Zn}, \mathrm{Y}, \mathrm{Zr}, \mathrm{Sr}, \mathrm{Cu}$ ); the second clastic group comprises compatible elements of mantle affinities ( $\mathrm{Mg}, \mathrm{Co}, \mathrm{Ni}, \mathrm{Cr}$ ); and the third group includes elements related to certain geochem$\mathrm{ical} /$ mineralogical processes and includes $\mathrm{Ca}, \mathrm{Sr}, \mathrm{Ba}$ and $\mathrm{V}$. Ca and $\mathrm{Sr}$ are related at least partly to the carbonate component in the sediments, both biogenic and clastic, while $\mathrm{Ba}$ and $\mathrm{V}$ are associated with the $\mathrm{C}_{\text {org }}$ being enriched in the sapropel S1 horizon.

Organic carbon. The $\mathrm{C}_{\text {org }}$ content in core ST5 varies considerably and ranges from 0.44 to 1.73 wt.\% (Fig. 8a), with the maximum values occurring in the sapropel S1 interval where the $\mathrm{C}_{\text {org }}$ content exceeds $1 \mathrm{wt} . \%$. The lower unit (S1a) and the upper unit (S1b) of the sapropel S1 sequence are characterized by a maximum $\mathrm{C}_{\text {org }}$ content of 1.77 wt.\% and average contents of 1.30 and 1.34 wt.\%, respectively. Both the maximum $\mathrm{C}_{\text {org }}$ value and the greatest $\mathrm{Ba} / \mathrm{Al}$ ratio were recorded at a depth of $179.5 \mathrm{~cm}$ in a sample from the S1a layer. Generally, increased abundances of $\mathrm{C}_{\text {org }}$ are accompanied by similar increases in hydrogen and nitrogen content (data not shown). During the interruption of the sapropel $\mathrm{S} 1$ sequence, the $\mathrm{C}_{\text {org }}$ content decreases markedly to $0.74 \mathrm{wt} . \%$, but this is still greater than in the pre-sapropel levels.

\section{Chronostratigraphy and sedimentation rates in core ST5}

The calibrated ${ }^{14} \mathrm{C}$ radiometric ages obtained at 41.0, 100.0, 180.5 and $255.0 \mathrm{~cm}$ were $2086 \pm 30,4562 \pm 30,8900 \pm 30$ and $16,912 \pm 30$ years BP, respectively (Fig. 2). The apparent sedimentation rates calculated were $19.7 \mathrm{~cm} \mathrm{ka}^{-1}$ at the first and uppermost interval, $23.8 \mathrm{~cm} \mathrm{ka}^{-1}$ at the second interval, $18.6 \mathrm{~cm} \mathrm{ka}^{-1}$ at the third interval and $9.3 \mathrm{~cm} \mathrm{ka}^{-1}$ at the last interval. The depth of $180.5 \mathrm{~cm}$ corresponds to the base of the S1a sapropel bed (Fig. 2). The average sedimentation rate for the interval represented by the core is $17.3 \mathrm{~cm} \mathrm{ka}^{-1}$, which is significantly greater than the sedimentation rates in the Myrtoon Basin (south-west Aegean Sea) and the Cretan Sea, where the rates were 10.2 and $4.7 \mathrm{~cm} \mathrm{ka}^{-1}$, respectively (Leontopoulou et al., 2019).

\section{Discussion}

\section{Comparison with the cores in the north-west and south Aegean}

Core ST5 displays sedimentological, mineralogical and geochemical differences from cores C40 and TI13 from the south-west and south Aegean Sea, respectively (Leontopoulou et al., 2019). These differences are associated with provenance areas and regional 
current circulation patterns. Core ST5 is characterized by considerably greater sedimentation rates and displays an apparent inconsistency: although the sediments are considerably richer in the clay fraction and poorer in the sand fraction than their counterparts from cores C40 and TI13, the average $D_{50}$ of core ST5 is greater than the average $D_{50}$ of core TI13. This apparent inconsistency is explained by the coarser particle size in core ST5 compared to core TI13, a probable consequence of the vicinity of the core to the west Anatolian landmass.

In addition to the overestimation of the smectite relative to the remaining clay minerals when using the method of Biscaye (1965), which is a general observation for sediments throughout the south Aegean Sea, the sediments of core ST5 are characterized by two features distinguishing them from other Aegean sediments (cf. Leontopoulou et al., 2019): (1) the presence of chlorite as the dominant clay mineral and the abundance of serpentine; and (2) underestimation of illite in addition to kaolinite and chlorite when using the method of Biscaye (1965) (Fig. 7a). This suggests the sediment is supplied by mainly basic/ultrabasic source rocks and the occurrence of illite along with kaolinite and chlorite mainly in the silt fraction of the sediments. In addition, sorting has a limited influence on the distribution of clay minerals in the sediments of core ST5, as indicated by the lack of particular trends between either quartz and clay minerals (Fig. 5b) or quartz and the $\mathrm{I} / \mathrm{K}$ (data not shown). This is in contrast to the sediments from the south-west Aegean Sea and the Cretan Sea, which displayed evidence for the influence of sorting in the clay mineral composition (Leontopoulou et al., 2019). This suggests that all clay minerals except for smectite, along with quartz, participate in the silt fraction of the core ST5 sediments, indicating limited transportation of these sediments.

Furthermore, the sediments of core ST5 have greater $\mathrm{MgO}$ contents than their counterparts from cores C40 and TI13 (Leontopoulou et al., 2019), which is explained by the presence of chlorite, dolomite and serpentine (Table 1). The $\mathrm{MgO}$-bearing minerals are related to the predominance and provenance of the clastic component of the sediments. Indeed, although dolomite and $\mathrm{Mg}$-calcite have comparable abundances in the bulk ST5 sediments (Table 1), the clay fractions are considerably enriched in $\mathrm{Mg}$-calcite compared to dolomite based on the peak areas of these minerals. The latter mineral is absent or only present in trace amounts in the clay fractions. The presence of trace dolomite in the clay fractions compared to its abundance in the bulk sediments is indicative of a mainly clastic origin of this carbonate. The high sedimentation rate in core ST5 due to the supply of sediments from the nearby ophiolitic landmasses yielded abundant serpentine, amphibole and chlorite.

Previous work has suggested that the smectite in the south-east Aegean Sea sediments might have been supplied by rivers from the surrounding landmasses of Asia Minor (Aksu et al., 1995b; Rousakis et al., 2004; Ehrmann et al., 2007; Ergin et al., 2007, 2012; Poulos, 2009) with a significant/dominant contribution of Nile-derived sediments and sediments from south Turkey (Cilicia) (Venkatarathnam \& Ryan, 1971; Ehrmann et al., 2007, 2013; Poulos, 2009). The crystal chemical characteristics of smectite in core ST5 are similar to those of core TI13 within the sapropel S1 and in the post-sapropel sediments, characterized by a high dehydroxylation temperature typical of cis-vacant octahedral sheets (Drits et al., 1998). Such smectites with low octahedral Fe contents and low tetrahedral charges are not of pedogenic but usually of volcanogenic origin, being present in bentonites formed from the alteration of acidic-intermediate volcaniclastic rocks. The smectites in pre-sapropel sediments contain both cisvacant and trans-vacant smectites (Fig. S1). By contrast, alteration of basic volcaniclastic rocks yields trans-vacant smectites (Christidis 2006; Fontaine et al., 2020). In addition, pedogenic smectites are usually Fe-montmorillonites and Fe-rich beidellites (Wilson, 1999). Such smectites have been described in sediments from the Nile River, the Cilicia Basin and north of Cyprus, in soils from the Ceyhan region of south Turkey, in the Cypriot bentonites and in vertisols in Turkey (Weir et al., 1975; Shaw \& Bush, 1978; Özkan \& Ross, 1979; Güzel \& Wilson, 1981; Christidis, 2006), being common in soils. In this sense, the decrease in the intensity of the 001 maximum of smectite in the pre-sapropel sediments after heating (Fig. S1) might indicate the coexistence of pedogenic smectite.

The formation of smectites in soils is controlled by low-lying topography, poor drainage and base-rich parent material (Borchardt, 1989). Thus, smectites are common in Mediterranean and temperate soils, which display limited leaching and are usually accompanied by illite (Thiry, 2000). Therefore, minor pedogenic smectite, if present, cannot be ascribed unequivocally to a specific source. However, certain mineralogical and geochemical trends in the sediments indicate that non-Aegean sources are unlikely to have contributed to the observed sedimentary patterns. This is discussed in the following section.

\section{Implications for sedimentation patterns in the south-east Aegean Sea}

The water circulation in the Aegean Sea is dominated by a general anticlockwise current of surface water, which consists of several small-scale eddies, the intensities and locations of which vary according to the seasonal wind field (Pinardi \& Masetti, 2000; Lykousis et al., 2002). Core ST5 was collected close to the area at which warm LSWs enters the Aegean Sea. Therefore, the proposed contribution of Nile and southern Turkey sediments that was mentioned previously (Venkatarathnam \& Ryan, 1971; Ehrmann et al., 2007, 2013; Poulos, 2009) would seem plausible.

However, there is ample evidence that the contribution of south-east Mediterranean sediments might not be significant in core ST5. Firstly, the core is characterized by a considerably greater sedimentation rate than the C40 and especially the TI13 cores from the south-west Aegean Sea and the Cretan Sea, respectively. The high sedimentation rate is attributed to the close proximity of the studied core to the western Turkey landmass, which provides abundant terrestrial sedimentary load through the discharge of the Buyük Menderes River, its tributaries and the smaller Dayan and Dalaman rivers. In addition, sediment supply from the nearby islands of Rhodes, Simi and Tilos and the volcanic island of Nisyros contributed to the high sedimentation rates.

Secondly, the abundances of serpentine and chlorite in the ST5 sediments strongly indicate the presence of ultrabasic source rocks. The nearby landmass of western Turkey is characterized by large outcrops from the melanges (Marmaris ophiolite) in the Lycian nappes (Yilmaz \& Yilmaz, 2013; Parlak, 2016; Güngör et al., 2018). The presence of greater proportions of hornblende than in the C40 and TI13 cores is also associated with the ophiolite rocks and it is attributed to weathering of amphibolites present in the Lycian nappes (Güngör et al., 2018). Serpentine is a common hydrothermal alteration product of olivine (Deer et al., 2013), which might also form during the alteration/lateritization 
of ultrabasic rocks (Christidis \& Mitsis, 2006; Villanova-deBenavent et al., 2017; Munoz et al., 2019). However, recent lateritic profiles are absent in the Lycian ophiolites. This is in accordance with the temperate climate in the broader area, which was interrupted by humid periods, during the Uppermost Pleistocene and Holocene. Therefore, serpentine is likely to have originated from erosion of the Lycian ophiolites.

Thirdly, the geochemical signature of the ST5 sediments, characterized by high $\mathrm{MgO}, \mathrm{Cr}, \mathrm{Ni}$ and Co contents (Table 2) and the positive trends of $\mathrm{MgO} v s \mathrm{Ni}, \mathrm{Cr}$ and $\mathrm{Co}$ (Fig. 9), is in full accord with geochemical control by ophiolites of the Lycian nappes. Two trends are distinguished in the diagrams shown in Fig. 9. The presapropel S1 sediments are characterized by greater $\mathrm{MgO}$ contents. When plotted on the $\mathrm{Y} / \mathrm{Ni}$ vs $\mathrm{Cr} / \mathrm{Ni}$ diagram used to trace the possible influence of ophiolite source rocks in the early Palaeozoic Taconic flysch (McLennan et al., 1993), all sediments plot close to the 'ophiolite pole' (Fig. 10). When compared to the Taconic flysch samples, the ST5 sediments have very low Y/Ni ratios, suggesting a limited contribution of non-ophiolite components. In addition, the sapropel S1 samples display a nearly constant $\mathrm{Y} / \mathrm{Ni}$ ratio, whereas the non-sapropel $\mathrm{S} 1$ sediments are characterized by greater variation in the Y/Ni ratio (see inset in Fig. 10). Moreover, the samples from the lowermost sections of the core have greater $\mathrm{Cr} / \mathrm{V}$ ratios. Hence, the nearby landmasses were major sources of sediments in core ST5, suggesting only limited transportation of the clastic components. In addition, the ample supply of clastic sediments reduced chemical sedimentation, yielding lower $\mathrm{Mg}$-calcite contents and low carbonate/clay mineral ratios throughout the core. By contrast, the riverine sediment supply from the Greek mainland is limited in the Myrtoon Basin (core C40) and in the Cretan Sea (core TI13), leading to greater calcite and $\mathrm{Mg}$-calcite contents and greater carbonate/clay mineral ratios (Leontopoulou et al., 2019). Finally, most of the smectites present have high dehydroxylation temperatures, being indicative of a volcanogenic origin (e.g. alteration of volcanic glass) rather than a pedogenic origin. Such smectites might have originated from erosion of the volcaniclastic rocks of Nisyros Island.

The contribution of aeolian material from the Sahara Desert is another component that might complicate provenance interpretations. In general, palygorskite has been used to indicate a Saharan origin of dust (Coudé-Gaussen et al., 1982; Molinaroli, 1996; Caquineau et al., 1998), although riverine input from the western Anatolia landmass might be an additional source (Chamley, 1989). Based on the data of Christidis et al. (2010), Leontopoulou et al. (2019) calculated that up to $50 \%$ of the kaolinite in cores C40 and TI13 might be attributed to Saharan dust. A similar kaolinite contribution from Saharan dust was calculated for core ST5 based on the data shown in Table 1, although the abundance of palygorskite was lower in core ST5 compared to cores C40 and TI13. The kaolinite content was also lower in core ST5 (Table 1). The main source of the remaining kaolinite probably originated from the nearby landmass, as the coastal sediments in the main river mouths in western Anatolia (e.g. Buyük Menderes, Dalyan, Dalaman) contain minor kaolinite (Bayhan et al., 2001; Ehrmann et al., 2007). However, the presence of abundant ophiolitic outcrops is not compatible with the formation of kaolinite during weathering due to the limited amount of $\mathrm{Al}$ present in ultrabasic rocks. Hence, pedogenic kaolinite is linked to weathering of the non-ophiolitic rocks of the Lycian nappes. By contrast, trans-vacant smectite in pre-sapropel sediments may form from weathering of ultrabasic rocks, and indeed

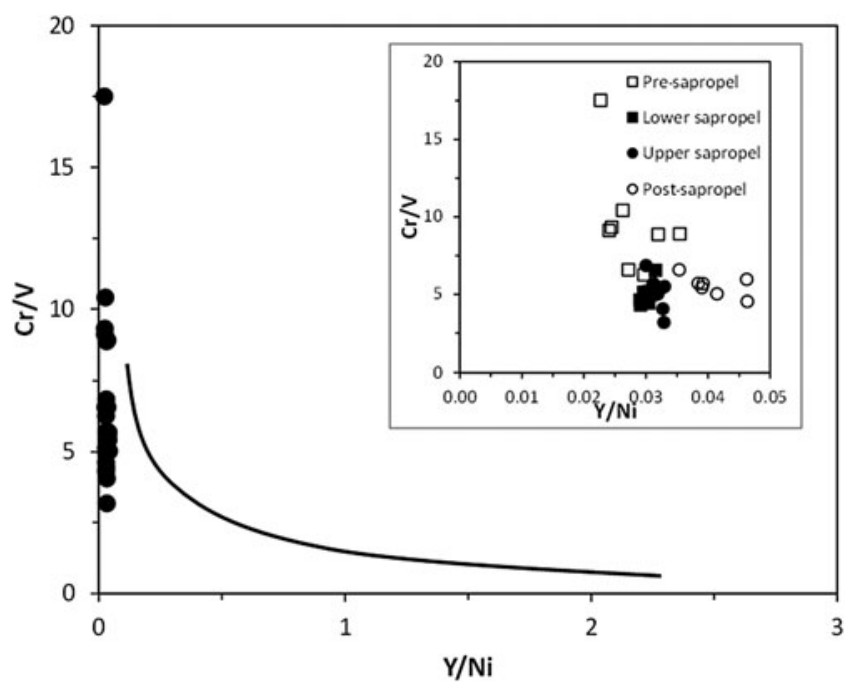

Fig. 10. Projection of the sediments in the $\mathrm{Y} / \mathrm{Ni}$ vs $\mathrm{Cr} / \mathrm{V}$ diagram (McLennan et al., 1993). The inset is a magnification at the low $\mathrm{Y} / \mathrm{Ni}$ ratio end. The curve indicates the trend of the Taconic flysch samples. See text for discussion.

Fe-rich smectites, containing minor octahedral Ni, are common weathering products of ultrabasic rocks (Decarreau et al., 1987; Gaudin et al., 2004, Christidis \& Skarpelis, 2010; Mano et al., 2014; Munoz et al., 2019). Hence, Fe-smectite might also be a source of $\mathrm{Ni}$, especially in the pre-sapropel sediments, reflecting the greater influence of the mantle component at these levels, as mentioned previously. Nevertheless, in general, serpentine and, to a lesser degree, talc are considered the major hosts of $\mathrm{Ni}$. The increase in smectite content upcore is compatible with the greater participation of the crustal component and parallels the increase in abundance of the cis-vacant smectite.

\section{Further implications of this study}

The suggested circulation pattern in the area is shown schematically in Fig. 11. Although core ST5 is within the trajectory of the currents coming in the south-east Aegean Sea from the south-east Mediterranean Sea, the main source of these sediments is the landmass of western Anatolia. In this pattern, local source areas in the west Anatolian landmass control the mineralogical and geochemical composition of sediments in the south-east Aegean Sea. Furthermore, overall marine circulation patterns are of limited importance for the deposition of recent sediments in these areas. Although the Aegean Sea is a relatively closed basin and such sedimentation patterns might be expected, marine circulation was important for sedimentation in the south-west Aegean Sea and the Cretan Sea (Leontopoulou et al., 2019). The greater influence of circulation patterns in the latter sites is attributed to the lack of significant riverine supply from the east Greek mainland and the Aegean Islands, including Crete. However, the role of local source areas in the composition of the sediments has been underestimated in previous studies. In addition, the reported well-defined clay mineral pattern characterized by large smectite/illite ratios in east and south Aegean sediments, due to the gradual increase in the smectite content towards the east (e.g. Ehrmann et al., 2007) does not seem to be valid because the smectite content was smaller in core ST5 compared than in core C40 (west Aegean Sea) and core TI13 (Cretan Sea). A significant contribution of Nilotic smectite would have increased the 


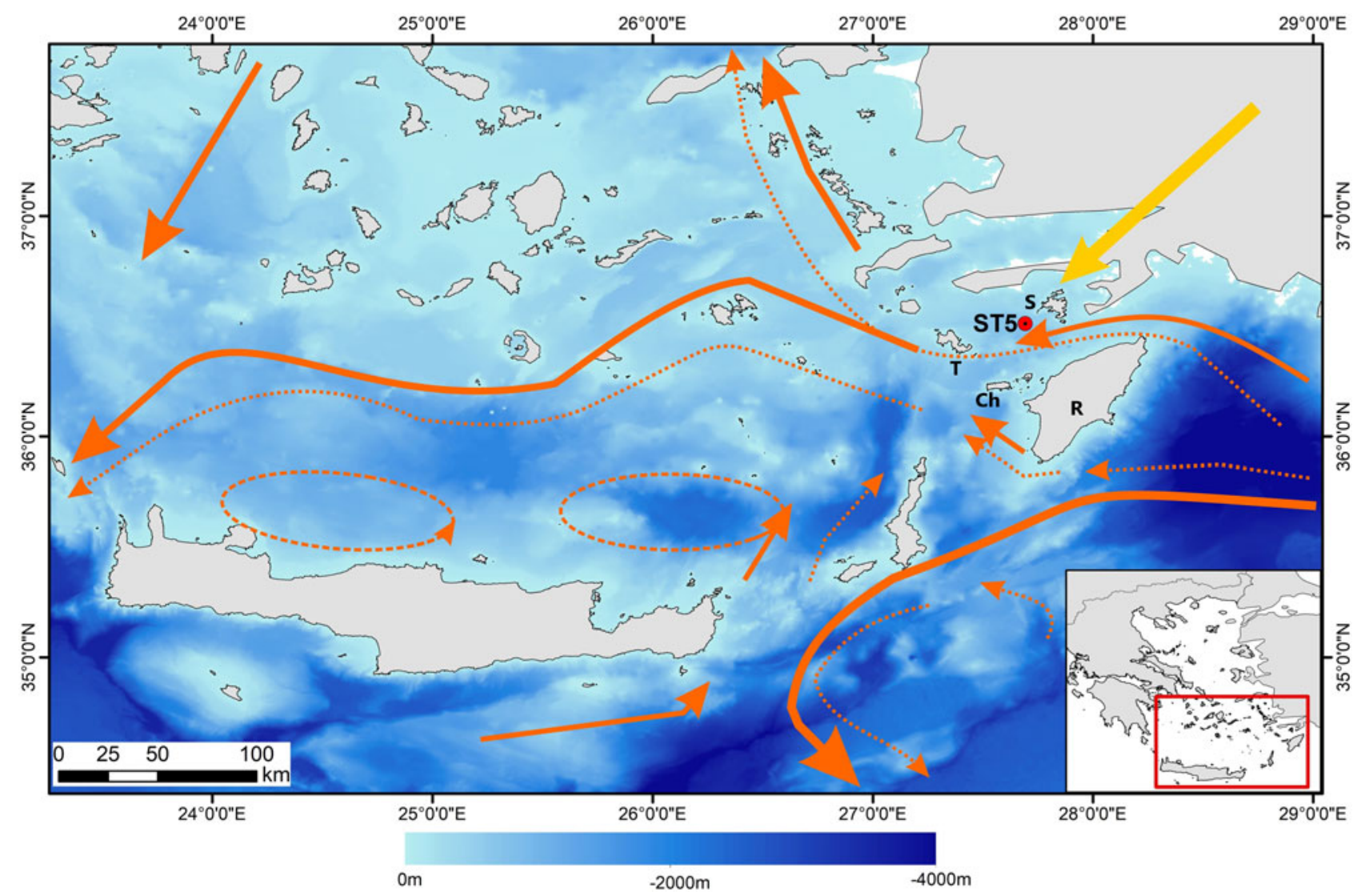

Fig. 11. Circulation of the surface waters (solid orange lines) and intermediate waters (dashed orange lines) (Estournel et al., 2021) and major terrigenous sediment source path (yellow arrow) in the study area. $\mathrm{Ch}=$ Chalki Island; $\mathrm{R}=\mathrm{Rhodes}$ Island; $\mathrm{S}=\mathrm{Symi}$ Island; $\mathrm{T}=$ Tilos Island.

smectite content of ST5 sediments. Additionally, in this case, the smectite should have a low dehydroxylation temperature.

The presence of abundant chlorite in the ST5 sediments is indicative of limited weathering of the source rocks, which is typical of glacial erosion (Thiry, 2000). However, the abundance of chlorite is at odds with the low $\mathrm{Al}_{2} \mathrm{O}_{3} / \mathrm{TiO}_{2}$ ratios, which indicate a humid climate during weathering, being favourable for the formation of kaolinite (Kiipli et al., 2012). This apparent contradiction is compatible with close lithological control of the nearby source areas regarding the composition of the ST5 sediments. The presence of numerous ophiolite outcrops and metamorphic rocks in the nearby Lycian nappes of the west Anatolian landmass, as well as the widespread limestone and dolomite outcrops in the nearby Rhodes, Symi, Chalki and Tilos islands (Papanikolaou, 2021), may provide a solution to this apparent contradiction. The pattern of the $\mathrm{Al}_{2} \mathrm{O}_{3} / \mathrm{TiO}_{2}$ ratios mimics those of the CIA values and illite contents, increasing towards the top of the sequence, whereas chlorite does not follow a clear trend with depth (Figs $3 \& 8 \mathrm{a}$ ). However, both serpentine and dolomite decrease gradually towards the top (Fig. 3), contributing to the decrease in $\mathrm{MgO}, \mathrm{Ni}$ and $\mathrm{Cr}$ in the same direction (Fig. 8a,b). The observed mineralogical and geochemical trends suggest that the sediment composition is controlled by provenance rather than by climate. Indeed, clear climatic control over the distribution of clay minerals would have caused a decrease of the chlorite content to match the CIA values.

The observed decreases in the serpentine contents towards the top of the sequence, coupled with the decrease in the $\mathrm{MgO}, \mathrm{Ni}$, and $\mathrm{Cr}$ on the one hand and the increase in the illite, smectite and $\mathrm{Al}_{2} \mathrm{O}_{3}$ contents, the $\mathrm{CIA}$ values and the $\mathrm{Al}_{2} \mathrm{O}_{3} / \mathrm{TiO}_{2}$ ratios in the same direction on the other, are compatible with a gradual change in the source areas from an ophiolite-enriched source to a crustal-enriched source. Moreover, the gradual decrease in $\mathrm{MgO}$ is mimicked by the abundance of $\mathrm{Mg}$-calcite in the sediments (Figs 3 \& 8a). Although dissolved $\mathrm{Mg}^{2+}$ is released during weathering of ultramafics and/or dissolution of dolomites, seawater composition is buffered with respect to the major cations such as $\mathrm{Mg}^{2+}$. The causes that triggered the gradual change in the sedimentation pattern are not known with certainty. A possible explanation might be a gradual transition to slightly drier climatic conditions, as indicated by the gradual increase in smectite and chlorite contents, the large particle sizes of chlorite and illite (mainly of coarse silt size) and the evolution of the $\mathrm{Al}_{2} \mathrm{O}_{3} / \mathrm{TiO}_{2}$ ratios. In any case, the gradually increasing contribution of additional sources from the eastern Mediterranean Sea should be excluded for three reasons: (1) particle size remained essentially unchanged throughout the sedimentation column, being dominated by the coarse silt fraction; (2) the abundance of smectite - the main phase, which has been assumed to have a Nilotic origin (Ehrmann et al. 2007, 2013; Poulos 2009) - follows a similar distribution pattern to illite (Fig. 4 \& inset in Fig. 8b), which has been transported from the west Anatolian mainland, suggesting a common source for the minerals; and (3) the abundance of key minerals such as chlorite, which is of local origin, remained relatively constant throughout the column.

Generally, in contrast to the C40 and TI13 cores from the south-west Aegean Sea and the Cretan Sea, respectively, the sapropel S1 sediments do not display significant differentiation 
in mineralogical and geochemical composition. There are only a few exceptions, such as the $\mathrm{C}_{\text {org }}$ content, the increasing abundance of amphibole and the greater concentrations of certain trace elements such as $\mathrm{V}$, $\mathrm{Co}$ and $\mathrm{Ba}$, which led to a large $\mathrm{Ba} / \mathrm{Al}$ ratio. Hence, the sedimentary influx did not fluctuate significantly during deposition of the sapropel, highlighting the control of the nearby landmasses over the sedimentary processes in the area during the entire time interval examined. These observations suggest that clay mineralogy based on traditional approaches and geochemical indices such as the CIA, the $\mathrm{Al}_{2} \mathrm{O}_{3} / \mathrm{TiO}_{2}$ ratio or similar indices should be used with caution for climatic interpretations in relatively closed basins surrounded by large landmasses such as the Aegean Sea. Whilst such indices might be reliable for tracing aeolian provenance in terrains with limited riverine supply, such as the central and western Mediterranean Sea (BoutRoumazeilles et al., 2007, 2013), they are of limited importance in the Aegean Sea, which is surrounded by large landmasses and the sedimentary record of which is dominated by considerable river supply, especially in the eastern and northern Aegean coasts.

\section{Conclusions}

The clay mineralogy and the geochemical record of sediments recovered from core ST5 in the south-east Aegean Sea showed evidence of substantial terrigenous input. By contrast, the accumulation of calcium carbonate in the marine sediments, which is mainly controlled by the productivity in the euphotic zone, is limited compared to the south-west Aegean Sea and the Cretan Sea, emphasizing the influence of the terrigenous supply of sediments from the nearby landmasses. The sediments are characterized by chlorite as the principal clay mineral and the presence of minor serpentine and amphibole as key tracer minerals, aiding in determining the provenance of the sediments. The geochemical fingerprinting of the sediments is dominated by abundant $\mathrm{MgO}, \mathrm{Ni}, \mathrm{Cr}$ and $\mathrm{Co}$, which, in association with the mineralogical signature, indicate supply from an ultrabasic source, probably the Marmaris ophiolite in the Lycian nappes.

Similar to the sediments from the Cretan Sea (Leontopoulou et al., 2019), the input of material from the south-east Mediterranean Sea seems to be of minor importance in the studied column, rendering previous suggestions for the origin of clay minerals questionable at least. Moreover, quantitative analysis of the non-clay fraction using reliable methods such as Rietveld refinement provides important information about the provenance of sediments, which are not traceable using traditional methods due to analytical constraints. Hence, in sedimentary environments characterized by controlled exchange with larger basins and sediment supply from the surrounding landmasses, quantitative bulk mineralogy coupled with analysis of the dehydroxylation behaviour of certain clay minerals, such as smectite, can be useful tools for tracing sediment provenance and may enable a more realistic assessment of the importance of water circulation patterns for sedimentation processes.

Supplementary material. To view supplementary material for this article, please visit https://doi.org/10.1180/clm.2022.2.

Acknowledgements. A. Stratakis assisted with the XRD analysis. E. Koutsopoulou assisted with the SEM work and E. Chamilaki with the CHNS measurements.

\section{References}

Adriaens R., Zeelmaekers E., Fettweis M., Vanlierde E., Vanlede J., Stassen P. et al. (2018) Quantitative clay mineralogy as provenance indicator for recent muds in the southern North Sea. Marine Geology, 398, 48-58.

Aksu A.E., Yaşar D. \& Mudie P.J. (1995a) Origin of late glacial-Holocene hemipelagic sediments in the Aegean Sea: clay mineralogy and carbonate cementation. Marine Geology, 123, 33-59.

Aksu A.E., Yaşar D., Mudie P.J. \& Gillespie H. (1995b) Late glacial-Holocene paleoclimatic and paleoceanographic evolution of the Aegean Sea: micropaleontological and stable isotopic evidence. Marine Micropaleontology, 25, 1-28.

Bayhan E., Ergin M., Temel A. \& Keskin Ş. (2001) Sedimentology and mineralogy of surficial bottom deposits from the Aegean-Çanakkale-Marmara transition (eastern Mediterranean): effects of marine and terrestrial factors. Marine Geology, 175, 297-315.

Biscaye P.E. (1965) Mineralogy and sedimentation of recent deep-sea clay in the Atlantic Ocean and adjacent seas and oceans. Geological Society of America Bulletin, 76, 803-832.

Bish D.L. \& Plötze M. (2011) X-ray powder diffraction with emphasis on qualitative and quantitative analysis in industrial mineralogy. Pp. 35-76 in: Advances in the Characterization of Industrial Minerals. EMU Notes in Mineralogy 9 (G.E. Christidis, editor). European Mineralogical Union and the Mineralogical Society of Great Britain and Ireland, London, UK.

Borchard G. (1989) Smectites. Pp. 675-727 in: Minerals in Soil Environments, 2nd ed. (J.B. Dixon \& S.B. Weed, editors). Soil Science Society of America, Madison, WI, USA.

Bout-Roumazeilles V., Combourieu Nebout N., Desprat S., Siani G., Turon J.-L. \& Essallami L. (2013) Tracking atmospheric and riverine terrigenous supplies variability during the last glacial and the Holocene in central Mediterranean. Climate of the Past, 9, 1065-1087.

Bout-Roumazeilles V., Combourieu Nebout N., Peyron O., Cortijo E., Landais A. \& Masson-Delmotte V. (2007) Connection between south Mediterranean climate and North African atmospheric circulation during the last 50,000 yr bp North Atlantic cold events. Quaternary Science Reviews, 26, 3197-3215.

Caquineau S., Gaudichet A., Gomes L., Magonthier M. \& Chatenet B. (1998) Saharan dust: clay ratio as a relevant tracer to assess the origin of soilderived aerosols. Geophysical Research Letters, 25, 983.

Chamley H. (1989) Clay Sedimentology. Springer Verlag, Berlin, Germany, 623 pp.

Christidis G.E. (2006) Genesis and compositional heterogeneity of smectites. Part III. Alteration of basic pyroclastic rocks. A case study from the Troodos Ophiolite Complex, Cyprus. American Mineralogist, 91, 685-701.

Christidis G.E. \& Mitsis I. (2006) A new Ni-rich stevensite from the ophiolite complex of Othrys, central Greece. Clays and Clay Minerals, 54, 653-666.

Christidis G.E. \& Skarpelis N. (2010) Clay mineralogy of the sedimentary iron-nickel ore of Agios Ioannis, NE Boeotia: new data and implicaiton for diagenetic modifications. Bulletin of the Geological Society of Greece, 43, 2553-2561.

Christidis G.E., Perdikatsis V. \& Apostolaki C. (2010) Mineralogy of the Saharan aeolian dust in Crete: examples from the period 2004-2009. Bulletin of the Geological Society of Greece, 43, 2570-2576.

Coudé-Gaussen G., Hillaire-Marcel C. \& Rognon P. (1982) Origine et évolution pédologique des fractions carbonatées dans les loess des Matmata (Sud-Tunisien) d'après leurs teneurs en ${ }^{13} \mathrm{C}$ et ${ }^{18} \mathrm{O}$. Comptes Rendus de l'Académie des Sciences de Paris, 295, 939-942.

Decarreau A., Colin F., Herbillon A., Manceau A., Nahon D., Paquet H. et al. (1987) Domain segregation in $\mathrm{Ni}-\mathrm{Fe}-\mathrm{Mg}$ smectites. Clays and Clay Minerals, 35, 1-10.

Deer W.A., Howie R.A. \& Zussman J. (2013) Rock Forming Minerals, 3rd ed. The MIneralogical Society, London, UK, 498 pp.

Dera G., Pellenard P., Neige P., Deconinck J.F., Pucéat E. \& Dommergues J.L. (2009) Distribution of clay minerals in Early Jurassic Peritethyan seas: palaeoclimatic significance inferred from multiproxy comparisons. Palaeogeography, Palaeoclimatology, Palaeoecology, 271, 39-51.

Drits V.A., Eberl D.D. \& Środoń J. (1998) XRD measurement of mean thickness, thickness distribution and strain for illite and illite-smectite crystallites by the Bertaut-Warren-Averbach technique. Clays and Clay Minerals, 46, 38-50. 
Ehrmann W., Schmiedl G., Hamann Y., Kuhnt T., Hemleben C. \& Siebel W. (2007) Clay minerals in late glacial and Holocene sediments of the northern and southern Aegean Sea. Palaeogeography, Palaeoclimatology, Palaeoecology, 249, 36-57.

Ehrmann W., Seidel M. \& Schmiedl G. (2013) Dynamics of late Quaternary North African humid periods documented in the clay mineral record of central Aegean Sea sediments. Global Planetary Change, 107, 186-195.

Ergin M., Bayhan E. \& Temel A. (2012) Clay mineral distribution in last glacial-Holocene sediment cores from the eastern Marmara Sea (Çınarcık Basin-Izmit Gulf transition), NW-Turkey: multisources and transport paths in a two-way flow system. Quaternary International, 261, 53-74.

Ergin M., Kadir S., Keskin Ş., Turhan-Akyüz N. \& Yaşar D. (2007) Late Quaternary climate and sea-level changes recorded in sediment composition off the Büyük Menderes River delta (eastern Aegean Sea, Turkey). Quaternary International, 167-168, 162-176.

Estournel C., Marsaleix P. \& Ulses C. (2021) A new assessment of the circulation of Atlantic and Intermediate Waters in the Eastern Mediterranean. Progress in Oceanography, 198, 102673.

Facorellis Y., Maniatis Y. \& Kromer B. (1998) Apparent ${ }^{14} \mathrm{C}$ ages of marine mollusk shells from a Greek island: calculation of the marine reservoir effect in the Aegean Sea. Radiocarbon, 40, 963-973.

Filippidi A., Triantaphyllou M.V. \& De Lange G.J. (2016) Eastern-Mediterranean ventilation variability during sapropel S1 formation, evaluated at two sites influenced by deep-water formation from Adriatic and Aegean seas. Quaternary Science Reviews, 144, 95-106.

Folk R.L. (1974) Petrology of Sedimentary Rocks. Hemphill Publishing Co., Austin, TX, USA, $170 \mathrm{pp}$.

Fontaine F, Christidis G.E., Yans J., Hollanders S., Hoffman A. \& Fagel N. (2020) Characterization and origin of two Fe-rich bentonites from Westerwald (Germany). Applied Clay Science 187, 105444.

Garzanti E., Padoan M., Setti M., López-Galindo A. \& Villa I.M. (2014) Provenance versus weathering control on the composition of tropical river mud (southern Africa). Chemical Geology, 366, 61-74.

Gaudin A., Grauby O., Noack N., Decarreau A. \& Petit S. (2004) Accurate crystal chemistry of ferric smectites from the lateritic nickel ore of Murrin Murrin (Western Australia). I. XRD and multi-scale chemical approaches. Clay Minerals, 39, 301-315.

Georgakopoulou M., Hein A., Müller N.S. \& Kiriatzi E. (2017) Development and calibration of a WDXRF routine applied to provenance studies on archaeological ceramics. X-Ray Spectrometry, 46, 186-199.

Geraga M., Tsaila-Monopolis S., Ioakim C., Papatheodorou G. \& Ferentinos G. (2000) Evaluation of palaeoenvironmental changes during the last 18,000 years in the Myrtoon Basin, SW Aegean Sea. Palaeogeography, Palaeoclimatology, Palaeoecology, 156, 1-17.

Gogou A., Bouloubassi L., Lykousis V., Arnaboldi M., Gaitani P. \& Meyers P.A. (2007) Organic geochemical evidence of late glacial-Holocene climate instability in the north Aegean Sea. Palaeogeography, Palaeoclimatology, Palaeoecology, 256, 1-20.

Güngör T., Akal C., Özer S., Hasözbek A., Sarı B. \& Mertz-Kraus R. (2018) Kinematics and $\mathrm{U}-\mathrm{Pb}$ zircon ages of the sole metamorphics of the Marmaris ophiolite, Lycian nappes, southwest Turkey. International Geology Review, 61, 1124-1142.

Güzel N. \& Wilson M.J. (1981) Clay-mineral studies of a soil chronosequence in southern Turkey. Geoderma, 20, 113-129.

Hughen K.A, Baillie M.G.L, Bard E., Warren Beck J., Bertrand C.J.H., Blackwell P.G. et al. (2004) Marine04 marine radiocarbon age calibration, 0-26 cal bp. Carbon, 46, 1059-1086.

Kadir S., Eren M., Külah T., Önalgill N., Cesur M. \& Gürel A. (2014) Genesis of Late Miocene-Pliocene lacustrine palygorskite and calcretes from Kırşehir, central Anatolia, Turkey. Clay Minerals, 49, 473-494.

Karageorgis A.P., Anagnostou C.L. \& Kaberi H. (2005) Geochemistry and mineralogy of the NW Aegean Sea surface sediments: implications for river runoff and anthropogenic impact. Applied Geochemistry, 20, 69-88.

Karageorgis A.P., Kanellopoulos T.D., Mavromatis V., Anagnostou C.L., Koutsopoulou E., Schmidt M. et al. (2012) Authigenic carbonate mineral formation in the Pagassitikos palaeolake during the latest Pleistocene, central Greece. Geo-Marine Letters, 33, 13-29.
Kemp S.J., Ellis M.A., Mounteney I. \& Kender S. (2016) Palaeoclimatic implications of high-resolution clay mineral assemblages preceding and across the onset of the Palaeocene-Eocene thermal maximum, North Sea Basin. Clay Minerals, 51, 793-813.

Kiipli E., Kiipli T., Kallaste T. \& Siir S. (2012) $\mathrm{Al}_{2} \mathrm{O}_{3} / \mathrm{TiO}_{2}$ ratio of the clay fraction of Late Ordovician-Silurian carbonate rocks as an indicator of paleoclimate of the Fennoscandian Shield. Palaeogeography, Palaeoclimatology, Palaeoecology, 365-366, 312-320.

Kronberg B.I., Nesbitt H.W. \& Lam W.W. (1986) Upper Pleiostocene deep-sea fan muds reflect chemical weathering of their mountainous source lands. Chemical Geology, 54, 283-294.

Leontopoulou G., Christidis G.E., Geraga M., Papatheodorou G. \& Koutsopoulou E. (2019) A novel mineralogical approach for provenance analysis of late Quaternary marine sediments: the case of Myrtoon Basin and Cretan Sea, Aegean, Greece. Sedimentary Geology, 384, 70-84.

Lister C.J., Hiscott R.N., Aksu A.E. \& Mudie P.J. (2015) Compositional trends through the Holocene mud succession of the southwestern Black Sea shelf: implications for sedimentary provenance and water-level history. Sedimentary Geology, 316, 13-25.

Lykousis V., Chronis G., Tselepides A., Price N.B., Theocharis A., Siokou-Frangou I. et al. (2002) Major outputs of the recent multidisciplinary biogeochemical researches undertaken in the Aegean Sea. Journal of Marine Systems, 33-34, 313-334.

Mano E.S., Caner L., Petit S., Chaves A.P. \& Mexias A.S. (2014) Mineralogical characterisation of Ni-bearing smectites from Niquelândia, Brazil. Clays and Clay Minerals, 62, 324-335.

Martinez-Ruiz F., Kastner M., Paytan A., Ortega-Huertas M. \& Bernasconi S.M. (2000) Geochemical evidence for enhanced productivity during S1 sapropel deposition in the eastern Mediterranean. Paleoceanography, 15, 200-209.

McLennan S.M., Hemming S., McDaniel D.K. \& Hanson G.L. (1993) Geochemical approaches to sedimentation, provenance, and tectonics. Special Papers - Geological Society of America, 285, 21-40.

Mercone D., Thomson J., Abu-ZiedI R.H., Croudace W. \& Rohling E.J. (2001) High-resolution geochemical and micropalaeontological profiling of the most recent eastern Mediterranean sapropel. Marine Geology, 177, 25-44.

Meunier A., Caner L., Hubert F., El Albani A. \& Pret D. (2013) The weathering intensity scale (WIS): an alternative approach of the Chemical Index of Alteration (CIA). American Journal of Science, 313, 113-143.

Molinaroli E. (1996) Mineralogical characterization of Saharan dust with a view to its final destination in Mediterranean sediments. Pp. 153-162 in: The Impact of Desert Dust across the Mediterranean (S. Guerzoni \& R. Chester, editors). Kluwer Academic, Dordrecht, The Netherlands.

Munoz M., Ulrich M., Cathelineau M., \& Mathon O. (2019) Weathering processes and crystal chemistry of Ni-bearing minerals in saprock horizons of New Caledonia ophiolite. Journal of Geochemical Exploration, 198, 82-99.

Nesbitt H.W. \& Young G.M. (1982) Early Proterozoic climates and plate motions inferred from major elements chemistry of lutites. Nature, 299, 715-717.

Özkan A. \& Ross G.J. (1979) Ferruginous beidellites in Turkish soils. Soil Science Society of America Journal, 43, 1242-1248.

Papanikolaou D.I. (2021). TheGeology of Greece. Springer International Publishing, Berlin, Germany, 345 pp.

Parlak O. (2016) The tauride ophiolites of Anatolia (Turkey): a review. Journal of Earth Science, 27, 901-934.

Pinardi N. \& Masetti E. (2000) Variability of the large scale general circulation of the Mediterranean Sea from observations and modelling: a review. Palaeogeography, Palaeoclimatology, Palaeoecology, 158, 153-173.

Post J.E. \& Bish D.L. (1989) Rietveld refinement of crystal structures using powder X-ray diffraction data. Pp. 277-308 in: Modern Powder Diffraction. Reviews in Mineralogy 20 (D.L. Bish \& J.E. Post, editors). De Gruyter, Berlin, Germany.

Poulos S.E. (2009) Origin and distribution of the terrigenous component of the unconsolidated surface sediment of the Aegean floor: a synthesis. Continental Shelf Research, 29, 2045-2060.

Reimer P.J. \& McCormac F.G. (2002) Marine radiocarbon reservoir corrections for the Mediterranean and Aegean seas. Radiocarbon, 44, 159-166.

Rousakis G., Karageorgis A.P., Conispoliatis N. \& Lykousis V. (2004) Last glacial-Holocene sediment sequences in N. Aegean basins: structure, accumulation rates and clay mineral distribution. Geo-Marine Letters, 24, 97-111. 
Sabatier P., Dezileau L., Briqueu L., Colin C. \& Siani G. (2010) Clay minerals and geochemistry record from northwest Mediterranean coastal lagoon sequence: implications for paleostorm reconstruction. Sedimentary Geology, 228, 205-217.

Shaw H.F. \& Bush P.R. (1978) The mineralogy and geochemistry of the Recent surface sediments of the Cilicia Basin, northeast Mediterranean. Marine Geology, 27, 115-136.

Snellings R., Machiels L., Mertens G., \& Elsen J. (2010) Rietveld refinement strategy for quantitative phase analysis of partially amorphous zeolitized tuffaceous rocks. Geologica Belgica, 13, 183-196.

Stuiver M. \& Reimer P.J. (1993) Extended C-14 data-base and revised Calib 3.0 C-14 age calibration program. Radiocarbon, 35, 215-230.

Stuiver M., Reimer P.J., Bard E., Beck J.W., Burr G.S., Hughen K.A. et al. (1998) INTCAL98 radiocarbon age calibration, 24,000-0 cal bp. Radiocarbon, 40, 1041-1083.

Thiry M. (2000) Palaeoclimatic interpretation of clay minerals in marine deposits: an outlook from the continental origin. Earth-Science Reviews, 49, 201-221.

Thomson J., Nixon S., Summerhayes C.P., Schönfeld J., Zahn R. \& Grootes P.M. (1999) Sedimentology and geochemistry of the Iberian margin. Pangaea. Available at: https://doi.org/10.1594/PANGAEA.735613

Triantaphyllou M.V., Ziveri P., Gogou A., Marino G., Lykousis V., Bouloubassi I. \& Nunez N. (2009) Late glacial-Holocene climate variability at the southeastern margin of the Aegean Sea. Marine Geology, 266, 182-197.

Tripsanas E.K., Panagiotopoulos I.P., Lykousis V., Morfis I., Karageorgis A.P., Anastasakis G. \& Kontogonis G. (2016) Late Quaternary bottom-current activity in the south Aegean Sea re flecting climate-driven dense-water production. Marine Geology, 375, 99-119.

Vanderaveroet P., Averbuch O., Deconinck J.F. \& Chamley H. (1999) A record of glacial/interglacial alternations in Pleistocene sediments off New Jersey expressed by clay mineral, grain-size and magnetic susceptibility data. Marine Geology, 159, 79-92.

Van Santvoort P.J.M., de Lange G.J., Thomson J., Cussen H., Wilson T.R.S., Krom M.D. \& Ströhle K. (1996) Active post-depositional oxidation of the most recent sapropel (S1) in sediments of the eastern Mediterranean Sea. Geochimica et Cosmochimica Acta, 60, 4007-4017.

Venkatarathnam K. \& Ryan W.B.F. (1971) Dispersal patterns of clay minerals in the sediments of the eastern Mediterranean Sea. Marine Geology, 11, 261-282.

Villanova-De-Benavent C., Domènech C., Tauler E., Galí S., Tassara S. \& Proenza J.A. (2017) Fe-Ni-bearing serpentines from the saprolite horizon of Caribbean Ni-laterite deposits: new insights from thermodynamic calculations. Mineralium Deposita, 52, 979-992.

Weir A.H., Ormerod E.C. \& El Mansey I.M. (1975) Clay mineralogy of sediments of the western Nile Delta. Clay Minerals, 10, 369-386.

Wentworth C.K. (1922) A scale of grade and class terms for clastic sediments. Journal of Geology, 30, 377-392.

Wilson M.J. (1999) The origin and formation of clay minerals in soils: past, present and future perspectives. Clay Minerals, 34, 7-25.

Yilmaz A. \& Yilmaz H. (2013) Ophiolites and ophiolitic mélanges of Turkey: a review. Geological Bulletin of Turkey, 56, 65-114.

Zalasiewicz J., Williams M., Haywood A. \& Ellis M. (2011) The Anthropocene: a new epoch of geological time? Philosophical Transactions of the Royal Society A: Mathematical, Physical and Engineering Sciences, 369, 835-841.

Zeelmaekers E., Honty M., Derkowski A., Srodon J., De Craen M., Vandenberghe N.R. et al. (2015) Qualitative and quantitative mineralogical composition of the Rupelian Boom Clay in Belgium. Clay Minerals, 50, 249-272. 